\title{
WNT signaling - lung cancer is no exception
}

\author{
Judit Rapp ${ }^{1,2}$, Luca Jaromi ${ }^{1,2}$, Krisztian Kvell ${ }^{1,2}$, Gyorgy Miskei ${ }^{1,2}$ and Judit E. Pongracz ${ }^{1,2^{*}}$
}

\begin{abstract}
Since the initial discovery of the oncogenic activity of WNT ligands our understanding of the complex roles for WNT signaling pathways in lung cancers has increased substantially. In the current review, the various effects of activation and inhibition of the WNT signaling pathways are summarized in the context of lung carcinogenesis. Recent evidence regarding WNT ligand transport mechanisms, the role of WNT signaling in lung cancer angiogenesis and drug transporter regulation and the importance of microRNA and posttranscriptional regulation of WNT signaling are also reviewed.
\end{abstract}

\section{Background}

Lung cancer (LC) is one of the deadliest forms of cancer worldwide [1,2] affecting both genders [3, 4]. The two main types of LC-s are small cell lung cancer (SCLC) and non-small cell lung cancer (NSCLC). SCLC represents $15-20 \%$ of all LC cases and is the more aggressive form; it metastasizes early and therefore surgical intervention is rarely a therapeutic option [5]. On the other hand, NSCLC denotes $80-85 \%$ and can be further classified into adeno (AC)-, squamous cell (SCC) -, large cell (LCC) and various mixed type carcinomas [6]. Unfortunately, the majority of NSCLC patients are diagnosed at an advanced stage of the disease narrowing down therapeutic options and leading to a limited median survival of about 18 months [7]. Recent studies have confirmed that therapy-surviving cancer stem cells (CSC) play a cardinal role in drug resistance and therefore, rapid progression of the disease [8]. While the carcinogenic process in the lung can be traced back to genetic mutations, malfunctioning signaling pathways are also highly important modulators of tumor formation and individual features of the disease.

An increasing amount of evidence has shown that the WNT pathway is one of the main signaling pathways involved in maintaining lung homeostasis and that aberrant activation of this pathway may underlie several debilitating lung diseases. Similarly, to other human cancers, WNT

\footnotetext{
*Correspondence: pongracz.e.judit@pte.hu

'Department of Pharmaceutical Biotechnology, School of Pharmacy,

University of Pecs, Pecs, Hungary

${ }^{2}$ Szentagothai Research Centre, University of Pecs, Pecs, Hungary
}

signaling plays an important part in lung carcinogenesis. Interestingly, however, while some epigenetic changes that affect WNT pathway inhibitors are similar to those seen in other malignancies, genetic mutations of the WNT pathway are uncommon in NSCLCs [9].

This review will summarize some novel aspects of WNT signaling, what is currently known about WNT associated LC pathogenesis as well as some important features of WNT mediated events in LC therapies.

\section{The complexity of WNT signaling - Canonical and non-canonical WNT signaling pathways}

WNT proteins are secreted glyco-lipoprotein morphogens that are required during lung development for cell-fate specification, cell proliferation and the control of asymmetric cell division. In adults, WNT signaling is essential for stem cell maintenance for regulation of tissue homeostasis [10]. Most of the 19 WNT ligands and the 10 main receptors, Frizzleds (FZD) that have been identified in mammalian cells can be identified in the human lung $[9,11]$. The two main different WNT pathways include i) the betacatenin-dependent or canonical pathway, and ii) the beta-catenin-independent or non-canonical pathways including the planar cell polarity (PCP) and the WNT/ $\mathrm{Ca} 2+$ pathways (Fig. 1).

\section{Canonical or beta-catenin dependent WNT signaling.}

In the lung, the role of WNT signaling has been examined in detail by multiple studies which mostly focus on beta-catenin-dependent signaling. In the canonical pathway during the absence of WNT, a beta-catenin destruction 


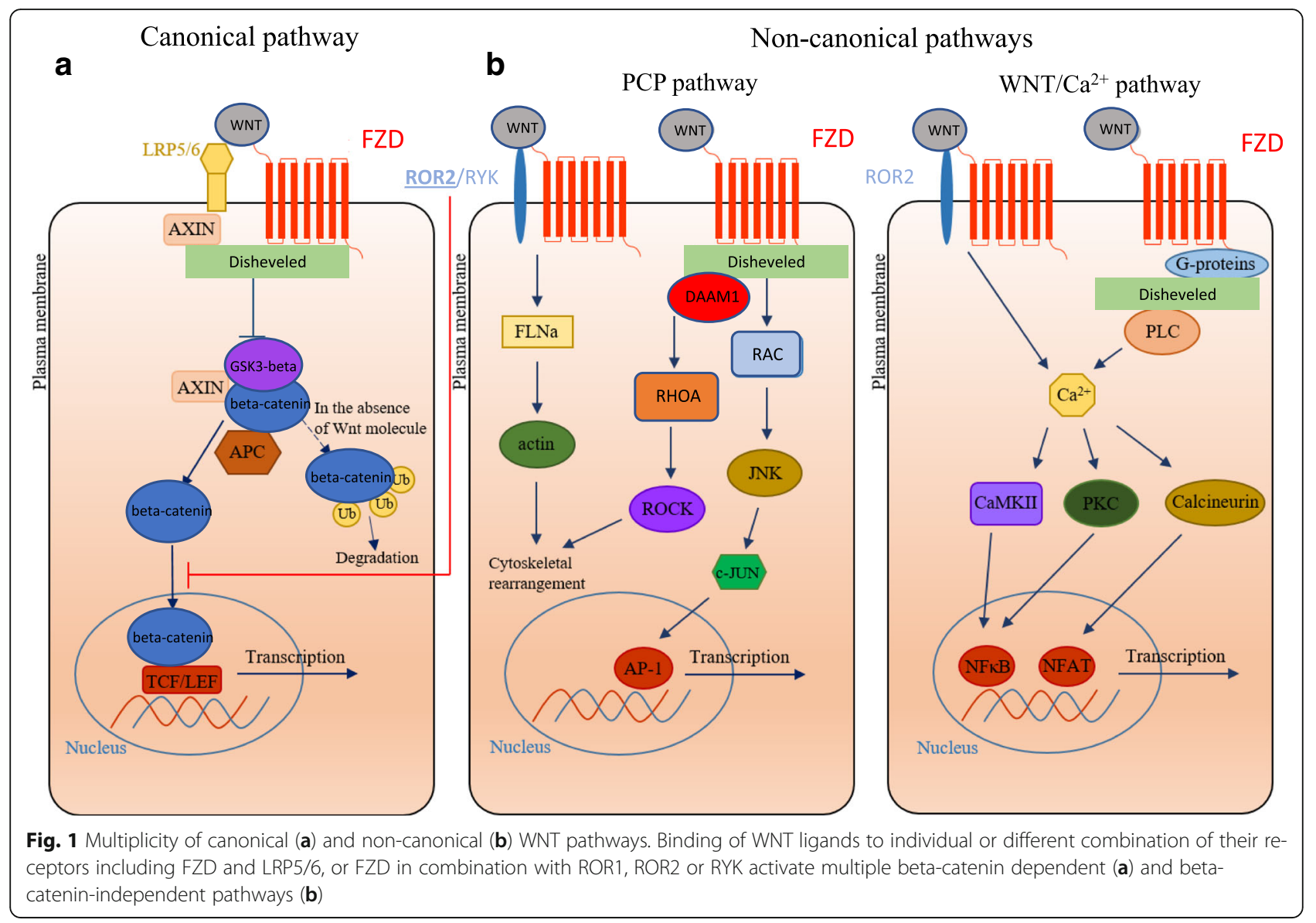

complex is assembled, consisting of: Axis inhibition protein (AXIN), adenomatous polyposis coli (APC), and glycogen synthase kinase 3-beta (GSK-3-beta) whereby beta-catenin is phosphorylated at serine and threonine sites and then proteolytically degraded $[9,12]$. If WNT is available to bind to one of the ten FZD receptors then a receptor complex between WNT, FZD, lipoprotein receptor-related protein (LRP), Disheveled (DVL), and AXIN is formed [9]. Within this active complex, DVL becomes phosphorylated and eventually inhibits GSK-3-beta resulting in reduced phosphorylation and consequently stops the proteolytic destruction of beta-catenin. Beta-catenin subsequently accumulates in the cytoplasm. The cytoplasmic betacatenin can then migrate to the nucleus and forms a complex with members of the T-cell factor (TCF)/ Lymphoid enhancer-binding factor (LEF) family of transcription factors and transcriptional coactivators including cAMP response element-binding protein (CREB)-binding protein (CBP) and $\mathrm{p} 300$. The many target genes include c-myc and cyclin D1 [9]. The transmembrane receptor tyrosine kinase orphan receptor ROR2 (which is important in non-canonical WNT signaling) may also be involved in canonical signaling via interactions with FZD2 [13]. ROR2 [14], as well as the other WNT-binding receptors such as receptor-like tyrosine kinase RYK [15], can therefore act as regulatory receptors for the betacatenin dependent WNT signaling.

\section{Non-canonical WNT signaling}

The two non-canonical WNT pathways are activated by several WNT ligands including WNT4, WNT5a, WNT7a, WNT11 and WNT16 [16-18]. Activation of the PCP signaling pathway, for example by WNT11, leads to the activation of the small GTPases RhoA (RAS homologue gene-family member A) and RAC1 (Ras-related C3 botulinum toxin substrate 1). This, in turn, activates the stress kinases JNK (Jun N-terminal kinase) and ROCK (Rhoassociated coiled-coil-containing protein kinase 1) that initiates remodeling of the cytoskeleton thus leading to changes in cell adhesion and motility [19-21].

The best known activator of Ca2 + -dependent WNT signaling is WNT5a. It triggers signal transduction via DVL-3, heterotrimeric G proteins and phospholipases [22]. Activation of this pathway leads to a transient increase in cytoplasmic free $\mathrm{Ca} 2+$ level that in turn can activate the protein kinase $\mathrm{C}$ (PKC) family, CaMKII (calcium calmodulin mediated kinase II) and the phosphatase calcineurin [23]. Apart from the well-known 
Ca2 + -dependent WNT signaling pathway, a novel, FYN tyrosine kinase and Signal Transducer and Activator of Transcription (STAT3) transcriptional regulatormediated non-canonical WNT signaling pathway has also been identified in tumor cells [24].

Although WNT signaling pathways seem distinct, WNT proteins are promiscuous and can share receptors and regulate the expression of WNT signaling molecules, as well as modify WNT signaling pathway activity. Noncanonical WNT signaling, for example, represses canonical WNT activity via various mechanisms involving PKCalpha, CaMKII-Transforming growth factor beta-Activated Kinase (TAK)1, Nemo-like Kinase (NLK), Siah2 E3 ubiquitin ligase or calcineurin-NFAT [21, 25-28]. Reports describing activation of the canonical pathway by noncanonical WNT ligands also exist [21, 29] making WNT signaling difficult to decipher and even more difficult to modulate in cancer therapy.

\section{Functional variations of WNT signaling among cell types}

Functional analyses of the canonical and non-canonical WNT pathways revealed that the canonical, PCP and $\mathrm{Ca} 2+$ pathways regulate multiple cellular activities in the lung that are dependent on the specific cellular context. In most cell types, non-canonical WNT signaling regulates canonical WNT activity, which is also critical for many aspects of lung biology. In response to canonical WNT signaling for example, beta-catenin/TCF/LEF signaling is activated in different lung cell types including the primordial epithelium (PE), alveolar epithelium (AE), and adjacent mesenchyme [30]. Human tissue studies have highlighted that in the developing lung, beta-catenin is found mainly in the peripheral epithelium, LEF1 expression is detected in alveolar and bronchial epithelium, while TCF4 is observed in epithelium and mesenchyme [31]. Tissue-specific deletion of beta-catenin in lung epithelial cells of test animals led to disrupted lung morphogenesis, lack of differentiation of the peripheral lung, enhanced formation of the conducting airways and consequently to death at birth due to respiratory failure [32]. Furthermore, beta-catenin phosphorylation can also lead to respiratory defects. Phosphorylation of beta-catenin at tyrosine 489 stimulates its nuclear localization and fibroblast activation which is a characteristic feature of bronchopulmonary dysplasia [33]. While deletion of the non-canonical WNT5a causes hyper-thickening of the mesenchymal interstitium and over-branching of the epithelial airways [34], overexpression of WNT5a in the epithelium disrupts epithelialmesenchymal interaction and causes malformations in both the airway epithelium and the surrounding mesenchyme [35]. WNT5a also has a role in epithelial-mesenchymal transition (EMT) in LC; where expression of WNT5a and its receptor FZD2 have an inverse correlation with the expression of markers of epithelial differentiation, such as
EpCAM, E-cadherin or keratin. Expressions of WNT5a and FZD2 positively correlate with the expression of vimentin, $\mathrm{N}$-cadherin and fibronectin, which are wellknown mesenchymal markers and are used to identify EMT during carcinogenesis [36].

Consequently, constitutive activation of either the canonical or the non-canonical WNT pathways in the developing lung can result in non-differentiated, dysfunctional lung phenotypes that resemble certain subtypes of LCs [37]. In support of this, investigation of constitutive activation of beta-catenin has shown that hyperactive canonical WNT signaling may channel NSCLC carcinogenesis towards the adenocarcinoma subtype [38].

\section{WNT signaling in LC}

Various LC subtypes are believed to originate from stem cells in different histological parts of the lung. Adenocarcinoma, one of the NSCLC subtypes, has been reported to develop from various progenitor cells including alveolar type (AT) II cells, Clara cells, and bronchioalveolar stem cells (BASCs) [39-41]. The other NSCLC subtype, squamous cell carcinoma, initiates from basal cells [42] whereas SCLC is derived from pulmonary neuroendocrine cells (PNECs) [43]. Studies using genetic manipulation, however, have proved that such "histologically localized stem cell origin" approaches in LC are oversimplified. Overexpression of RAS for example in PNECs, a cell type thought to be the origin of SCLC leads to adenocarcinoma [44], while inactivation of p53 and Rb1 in ATII cells results in SCLC instead of adenocarcinoma [45]. Such studies indicate that driver mutations are more important than the cell of origin.

\section{Murine cancer models}

In murine models, activation of WNT signaling is associated with increased carcinogenic potential [46] especially if activation of canonical WNT signaling is triggered parallel with KRAS mutation $[47,48]$. This process is also observed in human LC [49]. In human lung adenocarcinoma cases KRAS mutations are missense mutations which introduce amino acid substitution at one of the positions 12,13 , or 61. The result of these mutations is constitutive activation of the KRAS signaling pathway and it has been shown that if activation of KRAS and WNT signaling are combined, the joint activation leads to increased tumor size [49]. While tumors in WNT1 transgenic mice regress as WNT signals are blocked, tumor growth becomes WNTindependent in p53-deficient mice [50]. In the KRAS G12D substitution induced lung adenocarcinoma mouse model, WNT signaling enhances proliferation and EMT. Also, if down-regulation of SOX2 and upregulation of SOX9 and GATA6 simultaneously accompany KRAS mutation [51] then alterations in WNT signaling do not modulate the final outcome [48]. 
WNT pathway mutations differ in LC from other cancer types The most studied WNT pathway mutations in cancers include inherited and sporadic mutations in APC and beta-catenin genes. Since APC is part of the degradation scaffold for beta-catenin, mutations of APC result in reduced degradation and increased nuclear accumulation of beta-catenin, leading to activation of target oncogenes including cyclin D1 and c-myc [52]. Such mutations are not universal in all cancer types and while APC mutations occur more frequently in cancers of the colon, the lung is rarely affected by such mutations. A constitutively active beta-catenin-LEF1 fusion protein under tissue specific promoter control has been designed to express mutant, degradation-resistant beta-catenin to mimic the effect of mutation in the degradation scaffold [37]. The fusion protein was used to mimic the constitutive activation of betacatenin which has also been described in cancers of the lung. Increased levels of beta-catenin [53, 54] and loss of heterozygosity on chromosome $5 \mathrm{q}$, which contains the APC locus, have been observed in LC types (Table 1). While specific site mutations of the APC [55] or the betacatenin genes are rare in LCs, LC types are much better characterized by dysregulation of WNT ligand transcription [56-58]. For example, loss of WNT7a mRNA is a frequent feature of some LC cell lines and primary tumors [59]. NSCLC cells transformed with WNT7a show inhibition of anchorage independent growth via the JNK/AP1 dependent PCP signaling pathway [60]. In some other NSCLCs, elevated levels of WNT1 [61] and WNT2 [62] have been reported. Experimental inhibition of WNT2 induced signaling leads to down-regulation of the antiapoptotic gene, Survivin and consequently initiates apoptosis [62]. The Sox 2 gene coding the SOX2 transcription factor that is essential for maintaining self-renewal is also highly expressed in the main histological types of LCs [63]. Inhibition of SOX2 expression in lung adenocarcinoma induces apoptosis of tumor cells [64] and downregulates WNT1/2, Notch1, and c-myc gene expression. On the other hand, stabilization of beta-catenin signaling blocks Clara cell differentiation to ciliated cells [65], while deletion of beta-catenin in basal cells is able to suppress proliferation and triggers apoptosis [66]. Moreover, autocrine insulin-like growth factor-I (IGF-I) signaling induces WNT5a dependent trans-differentiation of ATII cells to ATI-like cells [67].

\section{Shifts between canonical and non-canonical WNT signaling modulate the carcinogenic process.}

A shift from canonical to non-canonical WNT signaling, or vice versa, has also been reported in certain NSCLS subtypes. Up-regulation of the canonical WNT7b was detected in adenocarcinomas, while increased expression of WNT5a was found in primary squamous cell carcinomas [68]. Additionally, although the metastatic stage of any tumors are associated with EMT [69] and generally linked to increased beta-catenin-dependent signaling [70], the non-canonical WNT5a, which also regulates fibroblast growth factor (FGF) 10 and sonic hedgehog $(\mathrm{SHH})$ expression [35], is overexpressed in lung metastases [71]. Matrix metalloproteinases, which are essential for tissue remodeling and are elevated in invasive cancers $[72,73]$, are target genes of both canonical and noncanonical WNT signaling pathways.

It is not only the WNT ligands, but also various signaling molecules that are dysregulated in LCs. For example, overexpression of DVL-3, a signal transducer molecule and positive regulator of WNT signaling pathways, was reported in $75 \%$ of primary NSCLCs compared to autologous matched normal tissue controls [74]. Down-regulation of WNT pathway antagonists, like Dickkopf-3 (DKK-3) [75], WNT inhibitory factor (WIF) [76, 77] and secreted Frizzled-Related Protein (sFRP) [78], have also been reported in various subtypes of LCs (summarized in Table 1).

\section{Genome-wide association studies and LC susceptibility}

Genome-wide association studies recently identified three LC susceptibility loci in chromosome regions 15q25, 5p15 and 6 p21 [79]. Importantly, the nicotinic acetylcholine receptor (nAChR) subunit genes are located on the $15 \mathrm{q} 25$ chromosomal region. As nAChRs are expressed on bronchial cells and bind tobacco-related carcinogens with higher affinity than nicotine itself, therefore it is not surprising that the risk of $\mathrm{LC}$ is drastically increased in smokers [80]. Nicotinc AChRs in general, and alpha7 nAChRs in particular have been linked to nicotine-stimulated proliferation of lung carcinoma cells [81]. The nicotine induced upregulation of WNT/PPAR-gamma (peroxisome proliferator activated receptor gamma) signaling can also regulate cigarette smoke-induced trans-differentiation of lung fibroblast to myofibroblasts that participate forming the cancerassociated stroma [82]. The BAT3 gene on the $6 \mathrm{p} 21$ locus affects p53 function and the cellular response to stress and apoptosis [83]. The same locus has also been associated with increased LC risk [80]. The telomerase reverse transcriptase (TERT) is located on the $5 \mathrm{p} 15$ locus and its modifications can cause aberrant proliferation and increased LC risk in both smokers and non-smokers [84]. The TERT-mediated developmental programs are similar to Myc and WNTmediated responses and therefore, the increased risk for proliferative diseases is not surprising [84]. Interestingly, a genome-wide association study conducted on people who had never smoked revealed a strong correlation between the reduced transcription level of the glypican-5 (GPC5) gene and genotypes of the replicated SNP (rs2352028 at 13q31.3) in lung adenocarcinomas. GPC5 is a member of the glypican gene family of heparin sulphate proteoglycans that control the signaling pathway of WNT, hedgehog $(\mathrm{HH})$, fibroblast growth factors (FGFs), and bone morphogenetic proteins 
Table 1 WNT ligands and signaling molecules associated with LC

\begin{tabular}{|c|c|c|c|}
\hline Gene & Function & Mutation type/level of expression & References \\
\hline APC & Part of beta-catenin destruction complex & $\begin{array}{l}\text { No mutation } \\
\text { Suppressed expression by promoter methylation }\end{array}$ & [184] \\
\hline AXIN & $\begin{array}{l}\text { Negative regulator of WNT signaling. } \\
\text { Promotes beta-catenin phosphorylation } \\
\text { which leads to beta-catenin degradation }\end{array}$ & $\begin{array}{l}\text { No mutation } \\
\text { Reduced expression }\end{array}$ & [185] \\
\hline \multirow[t]{2}{*}{ CTNNB1 } & $\begin{array}{l}\text { Main component of canonical signaling, } \\
\text { it serves as a transcription activator, } \\
\text { binding to TCF/LEF family }\end{array}$ & $\begin{array}{l}\text { Missense mutation of exon } 3 \text { results in substitution } \\
\text { of Ser/Thr residues }\end{array}$ & [38] \\
\hline & & $\begin{array}{l}\text { No mutation } \\
\text { Increased expression in cytoplasm and nuclear } \\
\text { compartment associated with poor prognosis }\end{array}$ & [186] \\
\hline DKK1 & $\begin{array}{l}\text { Binding to LRP } 5 / 6 \text { leads to its endocytosis } \\
\text { and inhibition of canonical signaling }\end{array}$ & Increased expression detected in serum & [187] \\
\hline DKK3 & Secreted WNT antagonist & $\begin{array}{l}\text { No mutation } \\
\text { Reduced expression }\end{array}$ & [188] \\
\hline DVL1 & $\begin{array}{l}\text { Required for FZD induced signaling } \\
\text { pathway activation }\end{array}$ & $\begin{array}{l}\text { No mutation } \\
\text { Increased expression associated with advanced stages }\end{array}$ & [189] \\
\hline DVL2 & & $\begin{array}{l}\text { No mutation } \\
\text { Increased expression is associated with advanced stages }\end{array}$ & [189] \\
\hline DVL3 & & $\begin{array}{l}\text { No mutation } \\
\text { Increased expression }\end{array}$ & [190] \\
\hline FZD8 & Receptor for WNT proteins & $\begin{array}{l}\text { No mutation } \\
\text { Increased expression }\end{array}$ & [191] \\
\hline GSK-3-beta & $\begin{array}{l}\text { Phosphorylates beta-catenin resulting } \\
\text { in beta-catenin degradation }\end{array}$ & $\begin{array}{l}\text { No mutation } \\
\text { Ser9 phosphorylation is associated with poor prognosis }\end{array}$ & [192] \\
\hline SFRP1 & $\begin{array}{l}\text { Inhibits WNT signaling by binding to } \\
\text { WNT proteins }\end{array}$ & $\begin{array}{l}\text { No mutation } \\
\text { Reduced expression regulated by promoter hypermethylation }\end{array}$ & [193] \\
\hline TCF4 & $\begin{array}{l}\text { Transcription factor that complexes } \\
\text { with beta-catenin upon activated } \\
\text { canonical WNT signaling }\end{array}$ & $\begin{array}{l}\text { No mutation } \\
\text { Increased expression in poorly differentiated tumor }\end{array}$ & [194] \\
\hline WIF1 & $\begin{array}{l}\text { Binding to WNT proteins to prevent } \\
\text { their interaction with receptors }\end{array}$ & $\begin{array}{l}\text { No mutation } \\
\text { Increased expression }\end{array}$ & [195] \\
\hline WNT1 & Non-canonical WNT ligand & $\begin{array}{l}\text { No mutation } \\
\text { Increased expression in NSCLC }\end{array}$ & [196] \\
\hline WNT11 & $\begin{array}{l}\text { WNT ligand which can activate both } \\
\text { canonical and non-canonical WNT pathway }\end{array}$ & $\begin{array}{l}\text { No mutation } \\
\text { Increased expression }\end{array}$ & [68] \\
\hline WNT2 & Canonical WNT ligand & $\begin{array}{l}\text { No mutation } \\
\text { Increased expression }\end{array}$ & [197] \\
\hline WNT3 & Canonical WNT ligand & $\begin{array}{l}\text { No mutation } \\
\text { Increased expression }\end{array}$ & [107] \\
\hline WNT5A & Non-canonical WNT ligand & $\begin{array}{l}\text { No mutation } \\
\text { Increased expression in SCC }\end{array}$ & [134] \\
\hline WNT7A & Non-canonical WNT ligand & $\begin{array}{l}\text { No mutation } \\
\text { Reduced expression due to promoter hypermethylation }\end{array}$ & [198] \\
\hline WNT7B & Canonical WNT ligand & $\begin{array}{l}\text { No mutation } \\
\text { Increased expression in AC }\end{array}$ & [199] \\
\hline
\end{tabular}

Most of the WNT pathway associated molecules are not mutated but the WNT signaling pathway is deregulated

(BMPs) which are all important regulators of cellular proliferation and differentiation [85].

\section{WNT ligands are "posted" in lipid envelopes}

Gradients of WNT proteins are essential for tissue maintenance. Importantly, WNT gradients lead to different gene expressions at certain points of the gradient in the tissue. Such concentration differences generated along the gradient might even explain how designated "canonical" and "non-canonical" WNT proteins can alternate between signaling pathways. How the gradient is maintained is not yet entirely clear. Due to their lipid residues, WNT proteins are highly hydrophobic; they attach tightly to cell membranes [86] and then insert 
themselves into the lipid bilayer. If the lipid residues are removed from the amino acid backbone, WNT proteins become biologically inactive [87]. Due to their lipid modifications, WNT ligands understandably cannot be directly secreted into aqueous body fluids (Fig. 2). Recent studies indicate that WNT signals are most likely to be transduced via lipid-coated particles including extracellular vesicles [88]. For decades, extracellular vesicles or exosomes have been disregarded as a potential route of cellular communication, but recently they have leaped into the center of interest. Lipid envelopes can influence longrange WNT signal gradients [89] via Reggie-1/flotillin-2 (FLOT2) [90], a major component of lipid microdomains in membranes that can promote WNT secretion and diffusion [91]. Recent studies have revealed that high FLOT2 expression both mRNA and protein level predict poor outcomes in NSCLC [92]. Such findings indicate that it is not just differential WNT expression but also WNT concentration at various points of its gradient, membrane availability of WNT ligands and endocytosis of specific WNT molecules can change during carcinogenesis, thus modulating cellular activity and potentially drug response.

\section{Posttranslational modifications of WNT pathway molecules in regulation of LC}

Secreted inhibitors and activators that regulate complex interactions within the complicated molecular network of WNT signaling [93] are under intense investigation. Epigenetic modulation, such as DNA methylation or histone deacetylation contributes to the deregulation of WNT signaling pathways. Down-regulation of several WNT signaling inhibitors have been reported in NSCLCs including AXIN, sFRPs 1-5, WIF-1, DKK-1, DKK-3, human homolog of Dapper (HDPR)1, runt-related transcription factor (RUNX)3, APC, caudal type homeobox (CDX)2, Dapper homolog (DACT)2, transmembrane protein (TMEM)88, Chibby, naked cuticle homolog (NKD1), empty spiracles homeobox (EMX)2, inhibitor of growth family (ING)4, and miR-487b. Although the mechanisms are not yet entirely clear, methylation and hypermethylation are the likely causes of reduced inhibitor levels [94, 95]. DACT 2 is one of the Dact gene family members, which inhibit canonical WNT signaling. If expression of DACT2 is lost due to hypermethylation of its promoter, then beta-catenin dependent signaling is no longer suppressed and uncontrollable proliferation ensues [96]. Similarly to

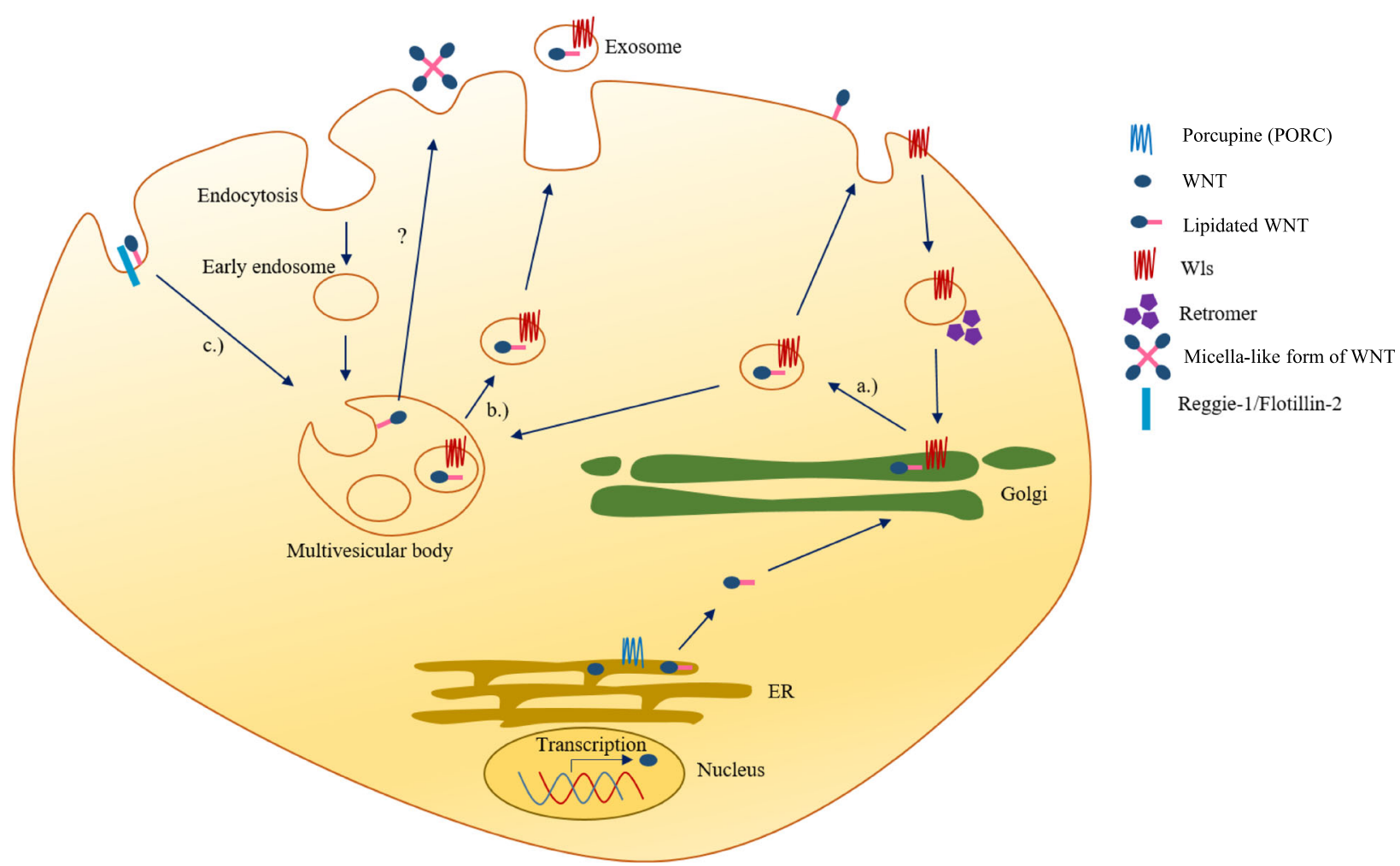

Fig. 2 Mechanism of WNT secretion. WNT ligand is secreted in the endoplasmatic reticulum (ER) and palmitoylated by Porcupine (PORC). a After releasing from the ER palmitolyated WNT enters the Golgi apparatus and Wls-coupled WNT travels to the plasma membrane. Then Wls is recycled from the plasma membrane and the retromer complex shuttles it back to the Golgi. b WNT-Wls complex can be transferred to the microvesicular body. Exosome can be produced from MVB that serves as a source of WNTs for long-range spread. $\mathbf{c}$ Reggie-1/Flotillin-2 can mediate the re-endocytosis of WNT molecules and may facilitate the transport of a more soluble micella-like form of WNTs [89] 
DACT2, GPC5 is downregulated in lung adenocarcinomas due to significant promoter hypermethylation. The methylation level of GPC5 promoter negatively correlates with its transcriptional expression and betacatenin dependent signaling [97]. Restoration of its WNT pathway inhibitory function results in reduced WNT signaling, decreased cell proliferation, and increased apoptosis. Apart from promoter methylation of WNT pathway inhibitors, methylation of the betacatenin promoter has also been described that leads to loss of beta-catenin protein expression and a poor prognosis in NSCLC patients [98].

Epigenetic modulation of the "anti-aging" Klotho [99] is also significant in carcinogenesis [100-102]. Klotho can act as an antagonist of the beta-catenin-dependent WNT signaling pathway; therefore overexpression of Klotho can reduce active beta-catenin and target c-myc and cyclin D1 levels [102], resulting in reduced proliferation. Supporting the above findings, down-regulation of Klotho increases cisplatin resistance while Klotho expression can attenuate resistance of LC to cisplatin-based chemotherapy and increase apoptosis [103]. Clinical survival analysis of various cancer types, however, has not demonstrated unequivocal involvement of Klotho in the carcinogenic process and it is still unclear whether the inconsistent role of Klotho in carcinogenesis is dependent on epigenetic variability or other factors [104, 105]. Recent discovery has exposed that apart from histone or DNA methylation of WNT signaling regulators, arginine methylation of the DVL-associated G3BP2 protein is a necessary post-translational modulation for LRP6 phosphorylation to initiate WNT3a induced canonical beta-catenin signaling from the receptor complex [106]. As WNT3a is one of the WNT ligands that promotes LC progression [107], investigation of methylation dependency of signaling molecules in the canonical signaling cascade can open up new therapeutic targets for drug discovery.

Methylation, however, is not the only posttranslational modification that modulates WNT signaling. AXIN, for example, can be destabilized by tankyrases [108] that regulate protein interactions and protein stability by poly-ADP-ribosylation. The post-translational modification of the N-terminal region of histone, by acetylation, methylation, ubiquitination, phosphorylation, or sumoylation, regulates DNA transcription, replication and repair. Recent epigenetic and transcriptomic profiling of human primary alveolar epithelial cells during in vitro differentiation revealed interactions amongst known regulatory pathways of distal alveolar epithelial cell differentiation. Interactions amongst the WNT signaling pathways, the transforming growth factor beta (TGF-beta) pathway, the hepatocyte nuclear factor 4 alpha (HNF4A) and the retinoid X receptor (RXR) signaling pathway [109] were strongly dependent on posttranslational changes.

\section{MicroRNAs targeting WNT signaling and LC}

The non-coding microRNAs or miRNAs suppress gene expressions by inhibiting translation or increasing degradation of target gene mRNAs [110]. miRNAs, similarly to WNT proteins and various lipophilic molecules are delivered to target cells mostly in extracellular vesicles that are shed into body fluids from a great variety of cells for secure "message" delivery. For diagnostic purposes, collecting cancer specific miRNAs from extracellular vesicles rather than serum is more reliable, as the extracellular vesicle protects miRNAs from degradation [111].

Several miRNAs have been identified in association with various types of LCs in recent years (Table 2). For example, down-regulation of miR-29 and let-7 were shown to be DNMT3A3B [112] and KRAS [113] targeting miRNAs, respectively, allowing upregulation of their targets. Meanwhile, KRAS, MYC, WNT5a, BMI1, and SUZ12 are targeted by miR-487b, which is down-regulated in certain types of LCs supporting the carcinogenic process [114]. Down-regulation of miR-214 levels was documented in cancer stem cells (CSCs) leading to stem cell marker expression including Nanog, OCT4, and SOX2 [115]. Amongst miR-214 targets in lung adenocarcinomas several betacatenin-interacting proteins were also found [115], while beta-catenin itself was rather affected by miR-3619-5p. miR3619-5p has been documented to suppress tumor growth in A549 and H460 NSCLC cell lines via binding to the 3 '-UPR region of the beta-catenin gene [116]. Additionally, overexpression of miR-376c inhibits the growth of NSCLC cells via a WNT-related orphan nuclear receptor, the liver receptor homolog-1 (LRH-1) [117].

Table 2 miRNAs regulating WNT signaling in LC

\begin{tabular}{lll}
\hline microRNA & Regulation & References \\
\hline miR-34a & Inhibits beta-catenin activity & {$[200]$} \\
miR-17-92 & Increases beta-catenin activity & {$[201]$} \\
miR-21 & Increases beta-catenin expression & {$[202]$} \\
miR-27b & Upregulated by WNT5a, inhibits vascular & {$[134]$} \\
& branching & \\
miR-29 & Downregulates beta-catenin expression & {$[203]$} \\
miR-31 & Decreases WNT antagonists and increases & {$[119]$} \\
& WNT5a & \\
miR-191 & Increases beta-catenin pathway activation & {$[204]$} \\
miR-374a & Targets WNT5a & {$[205]$} \\
miR-376c & Suppresses canonical WNT signaling & {$[117]$} \\
miR-410 & Activates beta-catenin pathway & {$[118]$} \\
miR-487b & Reduces WNT5a activity & {$[114]$} \\
miR-544a & Downregulates GSK3beta & {$[206]$} \\
miR-574-5p & Enhances beta-catenin phosphorlyation & {$[207]$} \\
miR-708 & Increases canonical WNT signaling & {$[208]$} \\
\hline
\end{tabular}


In contrast, miR-410 can accelerate tumor growth by suppressing the expression of SLC34A2, a type 2b sodium-dependent phosphate transporter (NaPi-IIb) that is located in the apical membrane of ATII cells. Decreased $\mathrm{NaPi}$-IIb levels have been shown to activate the WNT/betacatenin pathway leading to enhanced tumor growth and invasion [118]. Perhaps not surprisingly, miRNA expression is also regulated by one of the primary causes of LCs, cigarette smoke. miR-31 for example that targets the WNT pathway inhibitor DKK1 is triggered by cigarette smoke leading to enhanced tumorigenesis in the lung [119].

Although some miRNAs have not been directly associated with WNT signaling in NSCLCs, in other tumor types they have been demonstrated to play important WNT pathway regulatory function. For example miR-148b suppresses tumor growth via inhibiting canonical WNT signaling in hepatocellular carcinoma [120], while miR-499 can stimulate blood vessel formation via WNT signaling activation in various other tumor types [121]. Their precise role in LCs awaits further investigation.

\section{WNT signaling in LC angiogenesis}

WNT signaling has a fundamental role in both normal and tumor angiogenesis [122]. The canonical WNT pathway can regulate cadherin junctions in endothelial cell connections and therefore vascular permeability [123, 124]. Additionally, WNT signaling controls trans-endothelial migration of tumor cells via beta-catenin-dependent regulation of endothelial VE-, E- and N-cadherin expression [123-125]. The WNT-Ca2+ pathway -which is often referred to as a pro-angiogenic signaling pathway- induces endothelial cell proliferation and enhances capillary network formation, while activation of the PCP WNT pathway coordinates endothelial cell migration [126]. Activation of the PCP pathway via FZD4 impairs vascular morphogenesis [127], while activation of downstream components, such as DAAM-1 can reverse the changes [126]. The WNT/PCP pathway is responsible for impaired pericyte motility and as pericytes are important components of vessel formation and integrity, the balance of WNT pathways are important in forming and maintaining a functional lung vasculature [128]. Any imbalances in canonical and non-canonical WNT signaling could, therefore, modulate blood vessel formation in tumors and consequently affect therapeutic responses.

\section{Induction of neovascularization - Similarities and differences in LC subtypes}

Cancer cells can induce neovascularization when the solid tumor reaches more than $2 \mathrm{~mm}$ in diameter [129] and hypoxia occurs in the inner center of the tumor. Intra-tumor angiogenesis is best characterized by microvessel density. Extensive vascularization and higher vessel density indicate disease progression and predict a poor outcome in NSCLCs [130]. Amongst several other proangiogenic factors like Hypoxia-Inducible Factor (HIF)1alpha [131], Vascular Endothelial Growth Factor (VEGF)-A is of vital importance for endothelial cell proliferation and motility [132]. The pro-angiogenic factors are under complex molecular regulation. VEGF-A for example is documented to be under beta-catenin-dependent, canonical WNT control via a PPAR-gamma dependent mechanism [133]. Interestingly, PPAR-gamma down-regulation that is essential for VEGF-A up-regulation, can also be induced by a WNT5a triggered miR27b dependent manner [134]. Although tumors including NSCLC subtypes use the same molecular components to attract the necessary cell types for blood vessel formation as normal tissues, tumor vessels are often leaky, poorly differentiated and not hierarchic. This is due to differential WNT expression induced modulation of cellular morphology and function leading even to cellular mimicry of cells in the resident vascular network $[135,136]$. For instance, WNT5a signaling can induce vascular mimicry [137], while canonical pathway activation by WNT3a or WNT7b is associated with increased angiogenesis [138, 139].

\section{Angiogenesis and WNT target genes: Matrix metalloproteinases}

The canonical WNT pathway mediated EMT [140], which correlates with E-cadherin down-regulation [68] and VEGF-A up-regulation is associated with micrometastasis formation [141, 142]. Blood vessel formation in lung tumors, however, also need the WNT target proteolytic matrix metalloproteinase enzymes (MMPs) [143] that are responsible for degradation of the extracellular matrix components during new blood vessel formation or vessel branching. MMP-2, $-3,-7$ and MMP-9 have been shown to be important in NSCLCs [93] and angiogenesis in general [143]. One of the most studied enzymes is MMP-9 which degrades type IV collagen, modulates VEGF bioavailability through direct cleavage and also regulates vascular permeability [144]. In lung adenocarcinomas, MMP-9 levels correlate with increased risk of relapse [143, 145], although its direct regulation by canonical WNT3a signaling has only been studied in colorectal cancer [146]. MMP-7 is up-regulated by canonical WNT signaling and associated with increased invasion of LCs [147-149]. Additionally, up-regulation of MMP1 by the non-canonical WNT5a has also been shown in NSCLC [137]. Proteomic analysis of an Mmp1-/- mouse model revealed that tumor growth is hampered by the absence of MMP1 activity and is also associated with decreased levels of chitinase-3 like 3 (CHI3L3) and accumulation of the receptor for advanced glycation end-products (RAGE) and its ligand, S100A8 [150]. The molecules identified in the mouse model are important markers for lung development, aging and tumorigenesis. Upregulation of RAGE, 
for example, is observed in type I alveolar epithelial cells (ATI) during lung development, which process is associated with reduced beta-catenin-dependent WNT signaling [151]. Interestingly, during aging RAGE is highly expressed [152], while in malignant lung tumors RAGE is down-regulated [153, 154]. More studies are needed to explain such differences and to identify the primary role of RAGE in aging normal lung tissue and in LC.

\section{The angiogenic process as a therapeutic target}

As the angiogenic process is a therapeutic target in solid tumors, anti-angiogenic agents have become important in therapy. The anti-VEGF-A monoclonal antibody, bevacizumab is the first approved antiangiogenic agent to be applied in NSCLSs [155]. Despite some success of anti-angiogenic agents in cancer treatment, the expected break-through in cancer therapy has not occurred. A randomized phase II study investigated the effect of bevacizumab mono- and paclitaxel-carboplatinbevacizumab combination therapy. Although the latter combination increased progression free survival, serious hemorrhage was detected in some patients mostly with squamous histology [156]. As there is a well-documented difference in the WNT ligand profile of the two NSCLC subtypes [68], further studies of WNT controlled regulation of blood vessel formation is needed to more effectively stratify patients for the most appropriate anti-angiogenic treatment. The most worrying aspect is that in some cases - mostly in glioblastomas [157-160] administration of anti-angiogenic drugs contributed to formation of even more invasive tumors and failure of cytotoxic treatment.

\section{Maintenance of cancer stem cells and therapeutic resistance}

The accumulation of highly chemotherapy resistant cancer stem cells (CSC) are thought to play an important role in the incurability of LCs [161]. In CSCs beta-catenin dependent canonical WNT signaling is highly active and helps to maintain CSCs that express putative stem cell markers such as octamer-binding transcription factor 4 (OCT4) [162], Leucine-Rich Repeat-containing G-protein coupled receptor 5 (LGR5/GPR49), CD44, CD24, EpCAM [163], and cyclin D1 [11, 162]. The above markers are associated with increased cell proliferation rate and clone formation efficacy [164]. Such CSCs are highly resistant to several chemotherapeutic drugs [164] due to overexpression of ATP-binding cassette $(\mathrm{ABC})$ transporter protein G2 (ABCG2 or BCRP1) $[165,166]$ resulting in increased drug efflux [167]. Apart from ABCG2 the presence of other ATP-binding cassette $(\mathrm{ABC})$ transporter family members, such as ABCB1 (MDR1 or Pgp) are frequently tested as they are responsible for chemotherapeutic drug removal from cancer cells. Recently, the canonical WNT pathway dependent beta-catenin target TCF/LEF transcription factors were shown to activate the ABCB1 promoter indicating that WNT signaling is involved in the regulation of efflux transporter expression [168]. Studies of $\mathrm{ABCB} 1$ revealed that paclitaxel and irinotecan - the two drugs often used in cisplatin or carboplatin combination therapy of LCs $[169,170]$ - are both substrates of ABCB1. Cisplatin, a widely used drug in LC therapy, can also activate the canonical WNT pathway [162] which may explain the increased expression of efflux drug transporters including $A B C B 1$ and $A B C G 2$ correlating with reduced survival of NSCLC [171] and SCLC patients [172]. In contrast, inhibition of the beta-catenin dependent WNT pathway by high serum levels of the canonical pathway inhibitor DKK1 [173] has been detected in patients suffering from NSCLC and esophageal carcinoma. Increase in DKK1 levels was also associated with resistance to platina-based chemotherapy [174]. Based on previous research data, the role of WNT signaling in ABC transporter regulation appears contradictory, therefore more studies are needed to understand the molecular regulation and to identify potential therapeutic targets in WNT pathway associated chemoresistance.

Although increased expression of drug transporters in chemoresistant lung tumors suggests that the drug transporters might be useful therapeutic targets, sadly, clinical trials using $\mathrm{ABC}$ transporter inhibitors have not been successful. For example, the ABCB1 (MDR1) inhibitors tariquidar and CBT-1(R) [175-177] were tested unsuccessfully in two phase III clinical studies where treatment of stage IIIB/IV NSCLC patients with tariquidar in combination with vinorelbine or carboplatin/paclitaxel did not show any advantages and the trial was finished prematurely (ID NCT00042302 and NCT00042315) [178]. Additionally, inhibitors of efflux transporters can seriously damage the non-cancerous stem cell pool by increasing toxicity and enhancing the serious side effects of such therapies [179].

\section{Conclusions}

Complex deregulation of WNT signaling is an important element of lung carcinogenesis, controlling not just the carcinogenic process, but also tumor vascularization, drug response and disease progression. While current cancer research frequently cites the importance of precision medicine, therapeutic approaches and even drug development are still strongly focused on genetic mutations [180]. Individual variations in genetic driver and passenger mutations, along with non-mutated but deregulated signaling pathway combinations receive less attention, but can be just as important. Novel drugs are therefore under development to interfere with molecules of the WNT signaling pathway. Recently, NSCLC patients have been recruited into a clinical trial (NCT01957007) testing an anti-FZD7 antibody (OMP18R5 or Vantictumab) in combination therapy [181]. 
Further studies, however, are also needed to show the effect of WNT pathway interference on tumor cells and nontumor cells alike [182]. The WNT-receiving cells respond to WNT proteins in a concentration-dependent manner by activating different target genes. Simply, blocking a receptor therefore may result in different cellular response in tumor cells and non-tumor cells at various points of the WNT ligand concentration gradient. To understand such complexity, experimental models of human cancer tissues [183] are essential for future studies. This will allow us to expand our understanding of carcinogenesis beyond mutation analysis and allow intricate investigation of the tissue microenvironment and its effect on epigenetic signal modulation in carcinogenesis and therapeutic drug response.

\begin{abstract}
Abbreviations
ABC: ATP-binding cassette; $A B C B 1$ : ATP-binding cassette transporter protein B1; ABCG2: ATP-binding cassette transporter protein G2; AC: adenocarcinoma; AE: alveolar epithelium; AEC: alveolar epithelial cell; ALK: anaplastic limphoma kinase; AP: activator protein; APC: adenomatous polyposis coli; AT: alveolar type; AXIN: Axis inhibition protein; CaMKIl: calcium calmodulin mediated kinase; CBP: CREB-binding protein; CDX: caudal type homeobox; CHI3L3: chitinase-3 like 3; CREB: CAMP response element-binding protein; CSC: cancer stem cell; DAAM: disheveled associated activator of morphogenesis; DACT: Dapper homolog; DKK: Dickkopf-related protein; DNMT3A/3B: DNA methyltransferase 3 alpha/ 3 beta; DVL: Disheveled; E-cadherin: epithelial cadherin; EGFR: epidermal growth factor receptor; EMT: epithelial-mesenchymal transformation; EMX: empty spiracles homeobox; EpCAM: epithelial cell adhesion molecule; FGF: fibroblast growth factor; FLOT: flotillin; FRP: Frizzled-related protein; FZD: Frizzled receptor; GPC: glypican; GSK-3-beta: glycogen synthase kinase 3-beta; HDPR: human homolog of Dapper; HIF1alpha: hypoxia-inducible factor 1 alpha; HNF4A: hepatocyte nuclear factor 4 alpha; IGF: insulin-like growth factor; ING: inhibitor of growth family; JNK: Jun N-terminal kinase; LC: lung cancer; LCC: large cell carcinoma; LEF: lymphoid enhancer-binding factor; LGR: leucin-rich repeat containing G-protein coupled receptor; LRP: lipoprotein receptor-related protein; miRNA: microRNA; MMP: matrix metalloproteinase; N-cadherin: neural cadherin; NFAT: nuclear factor of activated T-cell; NKD: naked cuticle homolog; NLK: nemo-like kinase; NSCLC: non-small cell lung cancer; OCT: octamer-binding transcription factor; PCP: planar cell polarity; PE: primordial epithelium; PKC: protein kinase C; PNEC: pulmonary neuroendocrine cell; PPAR: peroxisome proliferator activated receptor; RAC1: Ras-related C3 botulinum toxin substrate 1; RAGE: receptor for advanced glycation end-product; Rb: retinoblastoma protein; RhoA: Ras homologue gene family member A; ROCK: Rhos-associated coiled-coilcontaining protein kinase 1; ROR2: receptor tyrosine kinase-like orphan receptor; RUNX: runt-related transcription factor; RXR: retionid X receptor; RYK: receptor-like tyrosine kinase; SCC: squamous cell carcinoma; SCLC: small cell lung cancer; SHH: sonic hedgehog; SLC: solute carrier transporter; STAT: signal transducer and activator of transcription; TAK: transforming growth factor beta-activated kinase; TCF: T-cell factor; TGFbeta: transforming growth factor beta; TMEM: transmembrane protein; VE-cadherin: vascular endothelial cadherin; VEGF-A: vascular endothelial growth factor A; VEGFR: vascular endothelial growth factor receptor; WIF: WNT inhibitory factor; WNT: wingless/int
\end{abstract}

\section{Acknowledgements}

The authors are indebted to Prof Emerita Mary Keen, Department of Pharmacy and Therapeutics, School of Clinical and Experimental Medicine, College of Medical and Dental Sciences, University of Birmingham, UK and Mr. Ricky Odedra, University of Pecs, Hungary for discussions and language editing.

\section{Availability of data and materials}

All data generated or analyzed during this study are included in this published article.

\section{Funding}

JEP was supported by the European Union and the State of Hungary, co-financed by the European Social Fund in the framework of TÁMOP4.2.4.A/2-11/1-2012-0001 'National Excellence Program'.

This work was also supported by the GINOP 2.3.2-15-2016-00022 grant. The project has been supported by the European Union, co-financed by the European Regional Development Fund.

\section{Authors' contributions}

$J R, \sqcup, G M, K K$ and JEP all performed literature search, have written specific sections of the manuscript. JR prepared the figures and finalized the reference list. JR and JEP have finalized the manuscript. All authors read and approved the final manuscript.

Ethics approval and consent to participate

Not applicable.

\section{Competing interests}

The author(s) declare(s) that they have no competing interests.

Received: 22 December 2016 Accepted: 27 August 2017

Published online: 05 September 2017

\section{References}

1. Minna JD, Roth JA, Gazdar AF. Focus on lung cancer. Cancer Cell. 2002;1:49-52.

2. Jemal A, Clegg LX, Ward E, Ries LAG, Wu X, Jamison PM, et al. Annual report to the nation on the status of cancer, 1975-2001, with a special feature regarding survival. Cancer [Internet]. 2004 [cited 2016 Jun 14];101:3-27. Available from: http://www.ncbi.nlm.nih.gov/pubmed/15221985.

3. Jemal A, Siegel R, Ward E, Hao Y, Xu J, Thun MJ. Cancer statistics, 2009. CACancer J. Clin. [Internet]. [cited 2015 Jul 16];59:225-249. Available from: http://www.ncbi.nlm.nih.gov/pubmed/19474385.

4. Ettinger DS, Akerley W, Borghaei H, Chang AC, Cheney RT, Chirieac LR, et al. NonSmall Cell Lung Cancer. J Natl Compr Canc Netw [Internet]. 2012 [cited 2015 Oct 21];10:1236-1271 Available from: http://www.jnccn.org/content/10/10/1236.full

5. Molina JR, Yang P, Cassivi SD, Schild SE, Adjei AA. Non-small cell lung cancer: epidemiology, risk factors, treatment, and survivorship. Mayo Clin. Proc. [Internet]. 2008 [cited 2014 Nov 16];83:584-594 Available from: http://www.pubmedcentral.nih.gov/articlerender.fcgi?artid=2718421 \&tool=pmcentrez\&rendertype $=$ abstract

6. D'Addario G, Früh M, Reck M, Baumann P, Klepetko W, Felip E. Metastatic non-small-cell lung cancer: ESMO Clinical Practice Guidelines for diagnosis, treatment and follow-up. Ann. Oncol. [Internet]. 2010 [cited 2015 Sep 12];21 Suppl 5:v116-v119 Available from: http://annonc.oxfordjournals.org/ content/21/suppl_5/v116.full

7. Stahel R, Peters S, Baas P, Brambilla E, Cappuzzo F, De Ruysscher D, et al. Strategies for improving outcomes in NSCLC: a look to the future. Lung Cancer [Internet]. 2013 [cited 2015 Oct 16];82:375-382. Available from: http://www.ncbinlm.nih.gov/pubmed/24094287.

8. He B, Barg RN, You L, Xu Z, Reguart N, Mikami I, et al. WNT signaling in stem cells and non-small-cell lung cancer. Clin. Lung Cancer [Internet]. 2005 [cited 2016 Jun 14];7:54-60. Available from: http://www.ncbi.nlm.nih.gov/ pubmed/16098245.

9. Stewart DJ. WNT signaling pathway in non-small cell lung cancer. J. Natl. Cancer Inst. [Internet]. 2014 [cited 2015 Jun 17];106:djt356. Available from: http://www.ncbi.nlm.nih.gov/pubmed/24309006.

10. Nusse R, Fuerer C, Ching W, Harnish K, Logan C, Zeng A, et al. WNT signaling and stem cell control. Cold Spring Harb. Symp. Quant. Biol. [Internet]. 2008 [cited 2016 Oct 20];73:59-66. Available from: http://www. ncbi.nlm.nih.gov/pubmed/19028988.

11. Mazieres J, He B, You L, Xu Z, Jablons DM. WNT signaling in lung cancer. Cancer Lett. [Internet]. 2005 [cited 2016 Jun 14];222:1-10. Available from: http://www.ncbi.nlm.nih.gov/pubmed/15837535.

12. Gao C, Xiao G, Hu J. Regulation of WNT/ $\beta$-catenin signaling by posttranslational modifications. Cell Biosci. [Internet]. 2014 [cited 2017 Apr 10];4:13. Available from: http://www.ncbi.nlm.nih.gov/pubmed/24594309.

13. Li C, Chen H, Hu L, Xing Y, Sasaki T, Villosis MF, et al. Ror2 modulates the canonical WNT signaling in lung epithelial cells through cooperation with Fzd2. BMC Mol. Biol. [Internet]. BioMed Central; 2008;9:11 Available from: http://bmcmolbiol.biomedcentral.com/articles/10.1186/1471-2199-9-11. [cited 2016 Jun 14]. 
14. Mikels A, Minami $Y$, Nusse R. Ror2 receptor requires tyrosine kinase activity to mediate WNT5A signaling. J. Biol. Chem. [Internet]. American Society for Biochemistry and Molecular Biology; 2009 [cited 2016 Oct 20];284:3016730176. Available from: http://www.ncbi.nlm.nih.gov/pubmed/19720827.

15. Lu W, Yamamoto V, Ortega B, Baltimore D. Mammalian Ryk is a WNT Coreceptor required for stimulation of neurite outgrowth. Cell. 2004;119:97-108.

16. Komiya Y, Habas R. WNT signal transduction pathways. Organogenesis [Internet]. Taylor \& Francis; 2008 [cited 2017 Feb 3];4:68-75. Available from: http://www.ncbi.n/m.nih.gov/pubmed/19279717.

17. Bentzinger CF, von Maltzahn J, Dumont NA, Stark DA, Wang YX, Nhan K, et al. WNT7a stimulates myogenic stem cell motility and engraftment resulting in improved muscle strength. J Cell Biol. 2014;205

18. Movérare-Skrtic S, Henning P, Liu X, Nagano K, Saito H, Börjesson AE, et al. Osteoblast-derived WNT16 represses osteoclastogenesis and prevents cortical bone fragility fractures. Nat. Med. [Internet]. 2014 [cited 2016 Jun 14];20:1279_ 1288. Available from: http://www.ncbi.nlm.nih.gov/pubmed/25306233.

19. Vladar EK, Antic D, Axelrod JD. Planar cell polarity signaling: the developing cell's compass. Cold Spring Harb. Perspect. Biol. [Internet]. Cold Spring Harbor Laboratory Press; 2009 [cited 2017 Feb 3];1:a002964. Available from: http://www.ncbi.nlm.nih.gov/pubmed/20066108.

20. Wang Y. WNT/planar cell polarity signaling: a new paradigm for cancer therapy. Mol Cancer Ther. 2009;8

21. Li C, Bellusci S, Borok Z, Minoo P. Non-canonical WNT signalling in the lung. J. Biochem. [Internet]. 2015 [cited 2017 Feb 3];158:355-365. Available from: http://www.ncbi.nlm.nih.gov/pubmed/26261051.

22. Ma L, Wang Y, Malbon CC, Wang H-Y. Dishevelled-3 C-terminal His single amino acid repeats are obligate for WNT5a activation of non-canonical signaling. J. Mol. Signal. [Internet]. Ubiquity Press; 2010 [cited 2017 Feb 3];5: 19. Available from: http://www.ncbi.n/m.nih.gov/pubmed/21092292.

23. De A. WNT/Ca2+ signaling pathway: a brief overview. Acta Biochim. Biophys. Sin. (Shanghai). [Internet]. 2011 [cited 2016 Oct 19];43:745-56. Available from: http://www.ncbi.nlm.nih.gov/pubmed/21903638.

24. Gujral TS, Chan M, Peshkin L, Sorger PK, Kirschner MW, MacBeath G. A noncanonical Frizzled2 pathway regulates epithelial-mesenchymal transition and metastasis. Cell [Internet]. 2014 [cited 2016 Jun 14];159:844-856. Available from: http://www.ncbi.nlm.nih.gov/pubmed/25417160.

25. Lee JM, Kim IS, Kim H, Lee JS, Kim K, Yim HY, et al. RORalpha attenuates WNT/beta-catenin signaling by PKCalpha-dependent phosphorylation in colon cancer. Mol. Cell [Internet]. 2010 [cited 2016 Jun 14];37:183-195. Available from: http://www.ncbi.nlm.nih.gov/pubmed/20122401.

26. Ishitani T, Kishida S, Hyodo-Miura J, Ueno N, Yasuda J, Waterman M, et al. The TAK1-NLK mitogen-activated protein kinase cascade functions in the WNT-5a/Ca(2+) pathway to antagonize WNT/beta-catenin signaling. Mol Cell. Biol. [Internet]. 2003 [cited 2016 Jun 14];23:131-139. Available from: http://www.ncbi.nlm.nih.gov/pubmed/12482967.

27. Topol L, Jiang X, Choi H, Garrett-Beal L, Carolan PJ, Yang Y. WNT-5a inhibits the canonical WNT pathway by promoting GSK-3-independent beta-catenin degradation. J. Cell Biol. [Internet]. 2003 [cited 2016 Jun 14];162:899-908. Available from: http://www.ncbi.nlm.nih.gov/pubmed/12952940.

28. Saneyoshi T, Kume S, Amasaki Y, Mikoshiba K. The WNT/calcium pathway activates NF-AT and promotes ventral cell fate in Xenopus embryos. Nature [Internet]. 2002 [cited 2016 Jun 14];417:295-299. Available from: http://www. ncbi.nlm.nih.gov/pubmed/12015605.

29. Rao TP, Kühl M. An updated overview on WNT signaling pathways: a prelude for more. Circ. Res. [Internet]. 2010 [cited 2015 Jun 1];106:1798-1806 Available from: http://circres.ahajournals.org/content/106/12/1798.full

30. Tebar M, Destrée O, de Vree WJ, Ten Have-Opbroek AA. Expression of Tcf/ Lef and sFrp and localization of beta-catenin in the developing mouse lung. Mech. Dev. [Internet]. 2001 [cited 2016 Jun 14];109:437-440. Available from: http://www.ncbi.nlm.nih.gov/pubmed/11731265.

31. De Langhe SP, Reynolds SD. WNT signaling in lung organogenesis. Organogenesis [Internet]. Taylor \& Francis; 2008 [cited 2017 may 4];4:100-108. Available from: http://www.ncbi.nlm.nih.gov/pubmed/19279721.

32. Mucenski ML, Wert SE, Nation JM, Loudy DE, Huelsken J, Birchmeier W, et al. beta-Catenin is required for specification of proximal/distal cell fate during lung morphogenesis. J. Biol. Chem. [Internet]. American Society for Biochemistry and Molecular Biology; 2003 [cited 2017 Apr 11];278:40231-40238. Available from: http://www.ncbi.nlm.nih.gov/pubmed/12885771.

33. Sucre JMS, Vijayaraj P, Aros CJ, Wilkinson D, Paul M, Dunn B, et al. Posttranslational modification of $\beta$-catenin is associated with pathogenic fibroblastic changes in bronchopulmonary dysplasia. Am. J. Physiol. - Lung
Cell. Mol. Physiol. [Internet]. 2017 [cited 2017 May 4];312 Available from: http://ajplung.physiology.org/content/312/2/L186

34. Li C, Xiao J, Hormi K, Borok Z, Minoo P. WNT5a participates in distal lung morphogenesis. Dev. Biol. [Internet]. 2002 [cited 2016 Jun 14];248:68-81. Available from: http://www.ncbi.nlm.nih.gov/pubmed/12142021.

35. Li C, Hu L, Xiao J, Chen H, Li JT, Bellusci S, et al. WNT5a regulates Shh and Fgf10 signaling during lung development. Dev. Biol. [Internet]. 2005 [cited 2016 Jun 14]; 287:86-97. Available from: http://www.ncbi.nlm.nih.gov/pubmed/16169547.

36. Qin L, Yin YT, Zheng FJ, Peng LX, Yang CF, Bao YN, et al. WNT5A promotes stemness characteristics in nasopharyngeal carcinoma cells leading to metastasis and tumorigenesis. Oncotarget. 2015;6(12):10239-10252. Available from: https://www.ncbi.nlm.nih.gov/pmc/articles/PMC4496352/.

37. Okubo T, Hogan BLM. Hyperactive WNT signaling changes the developmental potential of embryonic lung endoderm. J. Biol. [Internet]. 2004 [cited 2016 Jun 14];3:11. Available from: http://www.ncbi.nlm.nih.gov/ pubmed/15186480.

38. Sunaga N, Kohno T, Kolligs FT, Fearon ER, Saito R, Yokota J. Constitutive activation of the WNT signaling pathway by CTNNB1 (beta-catenin) mutations in a subset of human lung adenocarcinoma. Genes Chromosomes Cancer [Internet]. 2001 [cited 2017 may 4];30:316-321. Available from: http://www.ncbi.nlm.nih.gov/pubmed/11170292.

39. Meuwissen R, Berns A. Mouse models for human lung cancer. Genes Dev. [Internet]. 2005 [cited 2016 Jun 14];19:643-664. Available from: http://www. ncbi.nlm.nih.gov/pubmed/15769940.

40. Kim CFB, Jackson EL, Woolfenden AE, Lawrence S, Babar I, Vogel S, et al. Identification of bronchioalveolar stem cells in normal lung and lung cancer. Cell [Internet]. 2005 [cited 2016 Jun 14];121:823-835. Available from: http://www.ncbi.nlm.nih.gov/pubmed/15960971.

41. Sutherland KD, Song J-Y, Kwon MC, Proost N, Zevenhoven J, Berns A. Multiple cells-of-origin of mutant K-Ras-induced mouse lung adenocarcinoma. Proc. Natl. Acad. Sci. U S A. [Internet]. 2014 [cited 2016 Jun 14];111:4952-4957. Available from: http://www.ncbi.nlm.nih.gov/pubmed/24586047.

42. Dakir ELH, Feigenbaum L, Linnoila RI. Constitutive expression of human keratin 14 gene in mouse lung induces premalignant lesions and squamous differentiation. Carcinogenesis [Internet]. 2008 [cited 2016 Jun 14];29:237784. Available from: http://www.ncbi.n/m.nih.gov/pubmed/18701433.

43. Song H, Yao E, Lin C, Gacayan R, Chen M-H, Chuang P-T. Functional characterization of pulmonary neuroendocrine cells in lung development, injury, and tumorigenesis. Proc Natl Acad Sci U S A. [Internet]. 2012 [cited 2016 Jun 14];109:17531-17536. Available from: http://www.ncbi.nlm.nih.gov/ pubmed/23047698.

44. Sunday ME, Haley KJ, Sikorski K, Graham SA, Emanuel RL, Zhang F, et al. Calcitonin driven $\mathrm{v}$-Ha-ras induces multilineage pulmonary epithelial hyperplasias and neoplasms. Oncogene [Internet]. Nature Publishing Group; 1999 [cited 2016 Jun 14];18:4336-4347 Available from: http://www.nature. com/doifinder/10.1038/sj.onc.1202810

45. Sutherland KD, Proost N, Brouns I, Adriaensen D, Song J-Y, Berns A. Cell of origin of small cell lung cancer: inactivation of Trp53 and Rb1 in distinct cell types of adult mouse lung. Cancer Cell [Internet]. 2011 [cited 2016 Jun 14];19: 754-764. Available from: http://www.ncbi.nlm.nih.gov/pubmed/21665149.

46. Vaughan AE, Halbert CL, Wootton SK, Miller AD. Lung cancer in mice induced by the jaagsiekte sheep retrovirus envelope protein is not maintained by rare cancer stem cells, but tumorigenicity does correlate with WNT pathway activation. Mol. Cancer Res. [Internet]. 2012 [cited 2016 Jun 14];10:86-95. Available from: http://www.ncbi.nlm.nih.gov/pubmed/22064658.

47. Lee S, Kang J, Cho M, Seo E, Choi H, Kim E, et al. Profiling of transcripts and proteins modulated by K-ras oncogene in the lung tissues of K-ras transgenic mice by omics approaches. Int. J. Oncol. [Internet]. 2009 Available from: http://www.ncbi.nlm.nih.gov/pubmed/19082487.

48. Pacheco-Pinedo EC, Durham AC, Stewart KM, Goss AM, Lu MM, Demayo FJ, et al. WNT/ $\beta$-catenin signaling accelerates mouse lung tumorigenesis by imposing an embryonic distal progenitor phenotype on lung epithelium. J. Clin. Invest. [Internet]. 2011 [cited 2016 Jun 14];121:1935-1945. Available from: http://www.ncbi.nlm.nih.gov/pubmed/21490395.

49. Pacheco-Pinedo EC, Morrisey EE. WNT and Kras signaling-dark siblings in lung cancer. Oncotarget [Internet]. Impact Journals, LLC; 2011 [cited 2017 may 5];2: 569-74. Available from: http://www.ncbi.nlm.nih.gov/pubmed/21753228.

50. Gunther EJ, Moody SE, Belka GK, Hahn KT, Innocent N, Dugan KD, et al. Impact of p53 loss on reversal and recurrence of conditional WNT-induced tumorigenesis. Genes Dev. [Internet]. 2003 [cited 2016 Jun 14];17:488-501. Available from: http://www.ncbi.nlm.nih.gov/pubmed/12600942. 
51. Hashimoto S, Chen H, Que J, Brockway BL, Drake JA, Snyder JC, et al. $\beta$ Catenin-SOX2 signaling regulates the fate of developing airway epithelium. J. Cell Sci. [Internet]. 2012 [cited 2016 Jun 14];125:932-942. Available from: http://www.ncbi.nlm.nih.gov/pubmed/22421361.

52. Venesio T, Balsamo A, Scordamaglia A, Bertolaso M, Arrigoni A, Sprujevnik T, et al. Germline APC mutation on the beta-catenin binding site is associated with a decreased apoptotic level in colorectal adenomas. Mod. Pathol. [Internet]. 2003 [cited 2016 Jun 14];16:57-65. Available from: http://www. ncbi.nlm.nih.gov/pubmed/12527714.

53. Kotsinas A, Evangelou K, Zacharatos P, Kittas C, Gorgoulis VG. Proliferation, but not apoptosis, is associated with distinct beta-catenin expression patterns in non-small-cell lung carcinomas: relationship with adenomatous polyposis coli and G(1)-to S-phase cell-cycle regulators. Am. J. Pathol. [Internet]. 2002 [cited 2016 Jun 14];161:1619-1634. Available from; http://www.ncbi.nlm.nih.gov/pubmed/12414510.

54. Sekine S, Shibata T, Matsuno Y, Maeshima A, Ishii G, Sakamoto M, et al. Betacatenin mutations in pulmonary blastomas: association with morule formation. J. Pathol. [Internet]. 2003 [cited 2016 Jun 14];200:214-221. Available from: http://www.ncbi.nlm.nih.gov/pubmed/12754743.

55. Ohgaki H, Kros JM, Okamoto Y, Gaspert A, Huang H, Kurrer MO. APC mutations are infrequent but present in human lung cancer. Cancer Lett. [Internet]. 2004 [cited 2016 Jun 14];207:197-203. Available from: http://www.ncbi.nlm.nih.gov/pubmed/15072829.

56. Nakayama S, Sng N, Carretero J, Welner R, Hayashi Y, Yamamoto M, et al. $\beta$ catenin contributes to lung tumor development induced by EGFR mutations. Cancer Res. 2014;74(20):5891-902. Available from: https://www. ncbi.nlm.nih.gov/pubmed/25164010.

57. Ueda M, Gemmill RM, West J, Winn R, Sugita M, Tanaka N, et al. Mutations of the beta- and gamma-catenin genes are uncommon in human lung, breast, kidney, cervical and ovarian carcinomas. Br J Cancer [Internet]. 2001 [cited 2016 Jun 14];85:64-68. Available from: http://www.ncbi.nlm.nih.gov/ pubmed/11437403.

58. Blanco D, Vicent S, Elizegi E, Pino I, Fraga MF, Esteller M, et al. Altered expression of adhesion molecules and epithelial-mesenchymal transition in silica-induced rat lung carcinogenesis. Lab Invest. [Internet]. 2004 [cited 2016 Jun 14];84:999-1012. Available from: http://www.ncbi.nlm.nih.gov/pubmed/15195114.

59. Calvo R, West J, Franklin W, Erickson P, Bemis L, Li E, et al. Altered HOX and WNT7A expression in human lung cancer. Proc Natl Acad Sci U S A. [Internet]. 2000 [cited 2016 Jun 14];97:12776-12781. Available from: http://www.ncbi.nlm.nih.gov/pubmed/11070089.

60. Winn RA, Marek L, Han S-Y, Rodriguez K, Rodriguez N, Hammond M, et al. Restoration of WNT-7a expression reverses non-small cell lung cancer cellular transformation through frizzled-9-mediated growth inhibition and promotion of cell differentiation. J Biol Chem [Internet]. 2005 [cited 2016 Jun 14];280: 19625-19634. Available from: http://www.ncbi.nlm.nih.gov/pubmed/15705594

61. He B, You L, Uematsu K, Xu Z, Lee AY, Matsangou M, et al. A monoclonal antibody against WNT-1 induces apoptosis in human cancer cells. Neoplasia [Internet]. [cited 2016 Jun 14];6:7-14. Available from: http://www.ncbi.nlm. nih.gov/pubmed/15068666.

62. You L, He B, Xu Z, Uematsu K, Mazieres J, Mikami I, et al. Inhibition of WNT2-mediated signaling induces programmed cell death in non-small-cell lung cancer cells. Oncogene [Internet]. 2004 [cited 2016 Jun 14];23:6170-6174. Available from: http://www.ncbi.nlm.nih.gov/pubmed/15208662.

63. Chen S, Xu Y, Chen Y, Li X, Mou W, Wang L, et al. SOX2 Gene Regulates the Transcriptional Network of Oncogenes and Affects Tumorigenesis of Human Lung Cancer Cells. Tao Q, editor. PLoS One [Internet]. Public Library of Science; 2012 [cited 2016 Jun 14];7:e36326 Available from: http://dx.plos. org/10.1371/journal.pone.0036326

64. Nakatsugawa M, Takahashi A, Hirohashi Y, Torigoe T, Inoda S, Murase $M$, et al. SOX2 is overexpressed in stem-like cells of human lung adenocarcinoma and augments the tumorigenicity. Lab Invest [Internet]. 2011 [cited 2016 Jun 14];91:1796-1804. Available from: http://www.ncbi. nlm.nih.gov/pubmed/21931300.

65. Reynolds SD, Zemke AC, Giangreco A, Brockway BL, Teisanu RM, Drake JA, et al. Conditional stabilization of beta-catenin expands the pool of lung stem cells. Stem Cells [Internet]. 2008 [cited 2016 Jun 14];26:1337-1346. Available from: http://www.ncbi.nlm.nih.gov/pubmed/18356571.

66. Smith MK, Koch PJ, Reynolds SD. Direct and indirect roles for $\beta$-catenin in facultative basal progenitor cell differentiation. Am J Physiol Lung Cell Mol Physiol. [Internet]. 2012 [cited 2016 Jun 14];302:L580-L594. Available from: http://www.ncbi.nlm.nih.gov/pubmed/22227204.
67. Ghosh MC, Gorantla V, Makena PS, Luellen C, Sinclair SE, Schwingshackl A, et al Insulin-like growth factor-I stimulates differentiation of ATII cells to ATI-like cells through activation of WNT5a. Am J Physiol Lung Cell Mol Physiol. [Internet]. 2013 [cited 2016 Jun 14];305:L222-L228. Available from: http://www.ncbi.nlm. nih.gov/pubmed/23709620.

68. Bartis D, Csongei V, Weich A, Kiss E, Barko S, Kovacs T, et al. Down-regulation of canonical and up-regulation of non-canonical WNT signalling in the carcinogenic process of squamous cell lung carcinoma. PLoS One [Internet]. 2013 [cited 2015 Jul 20];8:e57393 Available from: http://www.pubmedcentral.nih.gov/articlerender. fcgi?artid=3591434\&tool=pmcentrez\&rendertype=abstract

69. Taki M, Kamata N, Yokoyama K, Fujimoto R, Tsutsumi S, Nagayama M. Down-regulation of WNT-4 and up-regulation of WNT-5a expression by epithelial-mesenchymal transition in human squamous carcinoma cells. Cancer Sci. [Internet]. 2003 [cited 2016 Jun 14];94:593-597. Available from: http://www.ncbi.nlm.nih.gov/pubmed/12841867.

70. Brabletz T, Hlubek F, Spaderna S, Schmalhofer O, Hiendlmeyer E, Jung A, et al. Invasion and metastasis in colorectal cancer: epithelial-mesenchymal transition, mesenchymal-epithelial transition, stem cells and beta-catenin. Cells Tissues Organs [Internet]. 2005 [cited 2016 Jun 14];179:56-65. Available from: http://www. ncbi.nlm.nih.gov/pubmed/15942193.

71. Nakano T, Tani M, Ishibashi Y, Kimura K, Park Y-B, Imaizumi N, et al. Biological properties and gene expression associated with metastatic potential of human osteosarcoma. Clin Exp Metastasis [Internet]. 2003 [cited 2016 Jun 14];20:665-674. Available from: http://uww.ncbi.nlm.nih.gov/pubmed/14669798.

72. Kossakowska AE, Huchcroft SA, Urbanski SJ, Edwards DR. Comparative analysis of the expression patterns of metalloproteinases and their inhibitors in breast neoplasia, sporadic colorectal neoplasia, pulmonary carcinomas and malignant non-Hodgkin's lymphomas in humans. Br J Cancer [Internet]. 1996 [cited 2016 Jun 14];73:1401-1408. Available from: http://www.ncbi.nlm.nih.gov/pubmed/8645587.

73. McCawley LJ, Crawford HC, King LE, Mudgett J, Matrisian LM. A protective role for matrix metalloproteinase-3 in squamous cell carcinoma. Cancer Res. [Internet]. 2004 [cited 2016 Jun 14];64:6965-6972. Available from: http://www.ncbi.nlm.nih.gov/pubmed/15466188.

74. Uematsu K, He B, You L, Xu Z, McCormick F, Jablons DM. Activation of the WNT pathway in non small cell lung cancer: evidence of dishevelled overexpression. Oncogene [Internet]. 2003 [cited 2016 Jun 14];22:7218-7221. Available from: http://www.ncbi.nlm.nih.gov/pubmed/14562050.

75. Nozaki I, Tsuji T, lijima O, Ohmura Y, Andou A, Miyazaki M, et al. Reduced expression of REIC/Dkk-3 gene in non-small cell lung cancer. Int J Oncol. [Internet]. 2001 [cited 2016 Jun 14];19:117-121. Available from: http://www. ncbi.nlm.nih.gov/pubmed/11408931.

76. Wissmann C, Wild PJ, Kaiser S, Roepcke S, Stoehr R, Woenckhaus M, et al. WIF1, a component of the WNT pathway, is down-regulated in prostate, breast, lung, and bladder cancer. J Pathol [Internet]. 2003 [cited 2016 Jun 14];201:204-212. Available from: http://www.ncbi.nlm.nih.gov/pubmed/14517837.

77. Mazieres J, He B, You L, Xu Z, Lee AY, Mikami I, et al. WNT inhibitory factor-1 is silenced by promoter hypermethylation in human lung cancer. Cancer Res. [Internet]. 2004 [cited 2016 Jun 14];64:4717-4720. Available from: http://www.ncbi.nlm.nih.gov/pubmed/15256437.

78. Lee AY, He B, You L, Dadfarmay S, Xu Z, Mazieres J, et al. Expression of the secreted frizzled-related protein gene family is downregulated in human mesothelioma. Oncogene [Internet]. 2004 [cited 2016 Jun 14];23:6672-6676. Available from: http://www.ncbi.nlm.nih.gov/pubmed/15221014.

79. Landi MT, Chatterjee N, Yu K, Goldin LR, Goldstein AM, Rotunno M, et al. A genome-wide association study of lung cancer identifies a region of chromosome 5 p15 associated with risk for adenocarcinoma. Am J Hum Genet [Internet]. Elsevier; 2009 [cited 2017 may 5];85:679-691. Available from: http://www.ncbi.nlm.nih.gov/pubmed/19836008.

80. Marshall AL, Christiani DC. Genetic susceptibility to lung cancer-light at the end of the tunnel? Carcinogenesis [Internet]. 2013 [cited 2017 may 5];34: 487-502. Available from: http://www.ncbi.nlm.nih.gov/pubmed/23349013.

81. Roman J, Koval M. Control of lung epithelial growth by a nicotinic acetylcholine receptor: the other side of the coin. Am J Pathol. [Internet]. American Society for Investigative Pathology; 2009 [cited 2017 may 12];175: 1799-1801. Available from: http://www.ncbi.nlm.nih.gov/pubmed/19815701.

82. Sakurai R, Cerny LM, Torday JS, Rehan VK. Mechanism for nicotine-induced up-regulation of WNT signaling in human alveolar interstitial fibroblasts. Exp Lung Res [Internet]. 2011 [cited 2017 may 12];37:144-154. Available from: http://www.ncbi.nlm.nih.gov/pubmed/21133803.

83. Sasaki T, Gan EC, Wakeham A, Kornbluth S, Mak TW, Okada H. HLA-Bassociated transcript 3 (Bat3)/Scythe is essential for p300-mediated 
acetylation of p53. Genes Dev. [Internet]. Cold Spring Harbor Laboratory Press; 2007 [cited 2017 may 5];21:848-861. Available from: http://www.ncbi. nlm.nih.gov/pubmed/17403783.

84. Choi J, Southworth LK, Sarin KY, Venteicher AS, Ma W, Chang W, et al. TERT Promotes Epithelial Proliferation through Transcriptional Control of a Mycand WNT-Related Developmental Program. PLoS Genet. [Internet]. Public Library of Science; 2008 [cited 2017 May 5];4:e10 Available from: http://dx. plos.org/10.1371/journal.pgen.0040010

85. Li Y, Sheu C-C, Ye Y, de Andrade M, Wang L, Chang S-C, et al. Genetic variants and risk of lung cancer in never smokers: a genome-wide association study. Lancet Oncol. [Internet]. 2010 [cited 2017 may 12];11:321-330. Available from: http://www.ncbi.nlm.nih.gov/pubmed/20304703.

86. Bradley RS, Brown AM. The proto-oncogene int-1 encodes a secreted protein associated with the extracellular matrix. EMBO J. [Internet]. 1990 [cited 2016 Oct 20];9:1569-1575. Available from: http://www.ncbi.nlm.nih. gov/pubmed/2158444.

87. Willert K, Nusse R. WNT proteins. Cold Spring Harb Perspect Biol [Internet]. Cold Spring Harbor Laboratory Press; 2012 [cited 2016 Oct 20];4:a007864. Available from: http://www.ncbinlm.nih.gov/pubmed/22952392.

88. Korkut C, Ataman B, Ramachandran P, Ashley J, Barria R, Gherbesi N, et al. Trans-synaptic transmission of vesicular WNT signals through Evi/WNTless. Cell [Internet]. 2009 [cited 2016 Oct 20];139:393-404. Available from: http://www.ncbi.nlm.nih.gov/pubmed/19837038.

89. Lorenowicz MJ, Korswagen HC. Sailing with the WNT: charting the WNT processing and secretion route. Exp Cell Res. [Internet]. 2009 [cited 2016 Oct 19]; 315:2683-2689. Available from: http://www.ncbi.nlm.nih.gov/pubmed/19559695.

90. Arkhipova KA, Sheyderman AN, Laktionov KK, Mochalnikova V V, Zborovskaya IB, Lisanti M, et al. Simultaneous expression of flotillin-1, flotillin-2, stomatin and caveolin-1 in non-small cell lung cancer and soft tissue sarcomas. BMC Cancer [Internet]. BioMed Central; 2014 [cited 2016 Oct 20];14:100 Available from: http://bmccancer.biomedcentral.com/articles/ 10.1186/1471-2407-14-100

91. Katanaev VL, Solis GP, Hausmann G, Buestorf S, Katanayeva N, Schrock Y, et al. Reggie-1/flotillin-2 promotes secretion of the long-range signalling forms of Wingless and Hedgehog in Drosophila. EMBO J. [Internet]. 2008 [cited 2016 Oct 201;27:509-521. Available from: http://www.ncbi.nlm.nih.gov/ pubmed/18219274.

92. Wang Y-L, Yao W-J, Guo L, Xi H-F, Li S-Y, Wang Z-M. Expression of flotillin-2 in human non-small cell lung cancer and its correlation with tumor progression and patient survival. Int J Clin Exp Pathol. [Internet]. 2015 [cited 2016 Oct 20];8: 601-607. Available from: http://www.ncbi.nlm.nih.gov/pubmed/25755751.

93. Pongracz JE, Stockley RA. WNT signalling in lung development and diseases. Respir Res [Internet]. 2006 [cited 2015 Sep 9];7:15 Available from: http://www.pubmedcentral.nih.gov/articlerender.fcgi?artid= 1397816\&tool=pmcentrez\&rendertype=abstract

94. Stewart DJ. WNT signaling pathway in non-small cell lung cancer. J Natl Cancer Inst. [Internet]. 2014 [cited 2015 Jun 17];106:djt356 Available from: http://jnci.oxfordjournals.org/content/106/1/djt356.long

95. Suzuki M, Shigematsu H, Nakaiima T, Kubo R, Motohashi S, Sekine Y, et al. Synchronous Alterations of WNT and Epidermal Growth Factor Receptor Signaling Pathways through Aberrant Methylation and Mutation in Non Small Cell Lung Cancer. Clin Cancer Res. [Internet]. 2007 [cited 2016 Jun 14]; 13:6087-6092 Available from: http://clincancerres.aacrjournals.org/cgi/doi/10. 1158/1078-0432.CCR-07-0591

96. Wang $S$, Dong $Y$, Zhang $Y$, Wang $X, X u L$, Yang $S$, et al. DACT2 is a functional tumor suppressor through inhibiting WNT/ $\beta$-catenin pathway and associated with poor survival in colon cancer. Oncogene [Internet]. 2015 [cited 2016 Jun 14];34:2575-2585. Available from: http://www.ncbi.nlm. nih.gov/pubmed/25023701.

97. Yuan S, Yu Z, Liu Q, Zhang M, Xiang Y, Wu N, et al. GPC5, a novel epigenetically silenced tumor suppressor, inhibits tumor growth by suppressing WNT/B-catenin signaling in lung adenocarcinoma. Oncogene [Internet]. 2016 [cited 2016 Jun 14]; Available from: http://www.ncbi.nlm.nih. gov/pubmed/27157618.

98. Miao $Y$, Wang L, Zang $X$, Xu X, Jiang G, Fan C, Liu Y, Lin $X$, Yu J, Zhang $Y$, Wang E. Promoter methylation-mediated silencing of $\beta$-catenin enhances invasiveness of non-small cell lung cancer and predicts adverse prognosis. PLoS One. Public Library of Science. 2014;9

99. Kuro-o M. Klotho and the aging process. Korean J Intern Med. [Internet]. 2011 [cited 2016 Jun 14];26:113-122. Available from: http://www.ncbi.nlm. nih.gov/pubmed/21716585.
100. Chen B, Wang X, Zhao W, Wu J. Klotho inhibits growth and promotes apoptosis in human lung cancer cell line A549. J Exp Clin Cancer Res. [Internet]. 2010 [cited 2016 Jun 14];29:99. Available from: http://www.ncbi. nlm.nih.gov/pubmed/20642846.

101. Wang L, Wang X, Wang X, Jie P, Lu H, Zhang S, et al. Klotho is silenced through promoter hypermethylation in gastric cancer. Am J Cancer Res [Internet]. 2011 [cited 2016 Jun 14];1:111-119. Available from: http://www. ncbi.nlm.nih.gov/pubmed/21969138.

102. Chen B, Ma X, Liu S, Zhao W, Wu J. Inhibition of lung cancer cells growth, motility and induction of apoptosis by Klotho, a novel secreted WNT antagonist, in a dose-dependent manner. Cancer Biol Ther [Internet]. 2012 [cited 2016 Jun 14];13:1221-1228. Available from: http://www.ncbi.nlm.nih. gov/pubmed/22922788

103. Wang Y, Chen L, Huang G, He D, He J, Xu W, et al. Klotho Sensitizes Human Lung Cancer Cell Line to Cisplatin via PI3K/Akt Pathway. Sarkar D, editor. PLoS One [Internet]. Public Library of Science; 2013 [cited 2016 Jun 14];8: e57391 Available from: http://dx.plos.org/10.1371/journal.pone.0057391

104. Usuda J, Ichinose S, Ishizumi T, Ohtani K, Inoue T, Saji H, et al. Klotho is a novel biomarker for good survival in resected large cell neuroendocrine carcinoma of the lung. Lung Cancer [Internet]. 2011 [cited 2016 Jun 14];72: 355-359. Available from: http://www.ncbi.nlm.nih.gov/pubmed/21075474.

105. Iyoda A, Hiroshima K, Toyozaki T, Haga Y, Fujisawa T, Ohwada H. Clinical characterization of pulmonary large cell neuroendocrine carcinoma and large cell carcinoma with neuroendocrine morphology. Cancer [Internet]. 2001 [cited 2016 Jun 14];91:1992-2000. Available from: http://www.ncbi.nIm. nih.gov/pubmed/11391577.

106. Bikkavilli RK, Malbon CC. WNT3a-stimulated LRP6 phosphorylation is dependent upon arginine methylation of G3BP2. J Cell Sci. [Internet]. 2012 [cited 2016 Nov 22];125:2446-Malbon 56 Available from: http://jcs.biologists. org/cgi/doi/10.1242/jcs.100933

107. Nakashima N, Liu D, Huang C, Ueno M, Zhang X, Yokomise H. WNT3 gene expression promotes tumor progression in non-small cell lung cancer. Lung Cancer [Internet]. 2012 [cited 2017 may 15];76:228-234. Available from: http://www.ncbi.nlm.nih.gov/pubmed/22070884.

108. Haikarainen T, Krauss S, Lehtio L. Tankyrases: structure, function and therapeutic implications in cancer. Curr Pharm Des. [Internet]. 2014 [cited 2016 Oct 20];20: 6472-6488. Available from: http://www.ncbi.nlm.nih.gov/pubmed/24975604.

109. Marconett CN, Zhou B, Rieger ME, Selamat SA, Dubourd M, Fang X, et al. Integrated transcriptomic and epigenomic analysis of primary human lung epithelial cell differentiation. PLoS Genet. [Internet]. 2013 [cited 2016 Jun 14];9: e1003513. Available from: http://www.ncbi.nlm.nih.gov/pubmed/23818859.

110. Macfarlane L-A, Murphy PR. MicroRNA: Biogenesis, Function and Role in Cancer. Curr Genomics [Internet]. Bentham Science Publishers; 2010 [cited 2017 may 12]; 11:537-561. Available from: http://www.ncbi.nlm.nih.gov/pubmed/21532838.

111. Cheng L, Sharples RA, Scicluna BJ, Hill AF. Exosomes provide a protective and enriched source of miRNA for biomarker profiling compared to intracellular and cell-free blood. J Extracell. vesicles [Internet]. 2014 [cited 2016 Oct 20];3. Available from: http://www.ncbi.nlm.nih.gov/pubmed/24683445.

112. Fabbri M, Garzon R, Cimmino A, Liu Z, Zanesi N, Callegari E, et al. MicroRNA-29 family reverts aberrant methylation in lung cancer by targeting DNA methyltransferases $3 \mathrm{~A}$ and 3B. Proc Natl Acad Sci U S A. Internet]. 2007 [cited 2016 Jun 14];104:1580515810. Available from: http//wnw.ncbi.nlm.nih.gov/pubmed/17890317.

113. Osada H, Takahashi T. let-7 and miR-17-92: small-sized major players in lung cancer development. Cancer Sci. [Internet]. 2011 [cited 2016 Jun 14];102:917. Available from: http://www.ncbi.nlm.nih.gov/pubmed/20735434.

114. Xi S, Xu H, Shan J, Tao Y, Hong JA, Inchauste S, et al. Cigarette smoke mediates epigenetic repression of miR-487b during pulmonary carcinogenesis. J Clin Invest [Internet]. 2013 [cited 2016 Nov 22];123:12411261 Available from: http://www.jci.org/articles/view/61271

115. Qi W, Chen J, Cheng X, Huang J, Xiang T, Li Q, et al. Targeting the WNTRegulatory Protein CTNNBIP1 by microRNA-214 Enhances the Stemness and Self-Renewal of Cancer Stem-Like Cells in Lung Adenocarcinomas. Stem Cells [Internet]. 2015 [cited 2016 Jun 14];33:3423-3436. Available from: http://www.ncbi.nlm.nih.gov/pubmed/26299367.

116. Niu X, Liu S, Jia L, Chen J. Role of MiR-3619-5p in $\beta$-Catenin-Mediated Non-Small Cell Lung Cancer Growth and Invasion. Cell Physiol Biochem. [Internet]. 2015 [cited 2016 Jun 17];37:1527-1536. Available from: http://www.ncbi.nlm.nih.gov/pubmed/26512718.

117. Jiang W, Tian Y, Jiang S, Liu S, Zhao X, Tian D. MicroRNA-376c suppresses non-small-cell lung cancer cell growth and invasion by targeting LRH-1mediated WNT signaling pathway. Commun: Biochem. Biophys. Res; 2016. 
118. Zhang X, Ke X, Pu Q, Yuan Y, Yang W, Luo X, et al. MicroRNA-410 acts as oncogene in NSCLC through downregulating SLC34A2 via activating WNT/ $\beta$-catenin pathway. Oncotarget [Internet]. 2016 [cited 2016 Jun 23];7:1456914585. Available from: http://www.ncbi.nlm.nih.gov/pubmed/26910912.

119. Xi S, Yang M, Tao Y, Xu H, Shan J, Inchauste S, et al. Cigarette smoke induces C/EBP- $\beta$-mediated activation of miR-31 in normal human respiratory epithelia and lung cancer cells. PLoS One [Internet]. Public Library of Science; 2010 [cited 2016 Nov 22];5:e13764. Available from: http://www.ncbi.nlm.nih.gov/pubmed/21048943.

120. Zhang J, Shi Y, Hong D, Song M, Huang D, Wang C, et al. MiR-148b suppresses cell proliferation and invasion in hepatocellular carcinoma by targeting WNT1/ß-catenin pathway. Sci Rep. [Internet]. Nature Publishing Group; 2015 [cited 2016 Oct 20];5:8087 Available from: http://www.nature. com/articles/srep08087

121. Okamoto A, Asai T, Ryu S, Ando H, Maeda N, Dewa T, et al. Enhanced Efficacy of Doxorubicin by microRNA-499-Mediated Improvement of Tumor Blood Flow. J Clin Med. [Internet]. Multidisciplinary Digital Publishing Institute; 2016 [cited 2016 Oct 20];5:10 Available from: http://www.mdpi.com/2077-0383/5/1/10

122. Dejana E. The role of WNT signaling in physiological and pathological angiogenesis. Circ Res. [Internet]. 2010 [cited 2015 Oct 21];107:943-952. Available from: http://www.ncbi.nlm.nih.gov/pubmed/20947863.

123. Reis M, Liebner S. WNT signaling in the vasculature. Exp Cell Res. [Internet]. 2013 [cited 2016 mar 22];319:1317-1323. Available from: http://www.ncbi. nlm.nih.gov/pubmed/23291327.

124. Heuberger J, Birchmeier W. Interplay of cadherin-mediated cell adhesion and canonical WNT signaling. Cold Spring Harb Perspect Biol [Internet]. 2010 [cited 2016 Mar 4];2:a002915 Available from: http://www.pubmedcentral.nih.gov/ articlerender.fcgi?artid=2828280\&tool=pmcentrez\&rendertype=abstract

125. Qi J, Wang J, Romanyuk O, Siu C-H. Involvement of Src family kinases in Ncadherin phosphorylation and beta-catenin dissociation during transendothelial migration of melanoma cells. Mol Biol Cell [Internet]. 2006 [cited 2016 Mar 22];17: 1261-1272 Available from: http://www.pubmedcentral.nih.gov/articlerender. fcgi?artid=1382315\&tool=pmcentrez\&rendertype=abstract

126. Cirone $P$, Lin S, Griesbach HL, Zhang Y, Slusarski DC, Crews CM. A role for planar cell polarity signaling in angiogenesis. Angiogenesis [Internet]. 2008 [cited 2016 Mar 22];11:347-360 Available from: http://www.pubmedcentral.nih. gov/articlerender.fcgi?artid=3547076\&tool=pmcentrez\&rendertype=abstract

127. Descamps B, Sewduth R, Ferreira Tojais N, Jaspard B, Reynaud A, Sohet F, et al. Frizzled 4 regulates arterial network organization through noncanonical WNT/planar cell polarity signaling. Circ Res [Internet]. 2012 [cited 2016 mar 22];110:47-58. Available from: http://www.ncbi.n/m.nih.gov/pubmed/ 22076635.

128. Yuan K, Orcholski ME, Panaroni C, Shuffle EM, Huang NF, Jiang X, et al. Activation of the WNT/planar cell polarity pathway is required for pericyte recruitment during pulmonary angiogenesis. Am J Pathol. [Internet]. 2015 [cited 2016 Mar 22];185:69-84 Available from: http://www.pubmedcentral.nih. gov/articlerender.fcgi?artid=4278244\&tool=pmcentrez\&rendertype=abstract

129. Folkman J. Tumor angiogenesis: therapeutic implications. N Engl J Med. [Internet]. 1971 [cited 2016 Jun 14];285:1182-1186. Available from: http:// www.ncbi.n/m.nih.gov/pubmed/4938153.

130. Herbst RS, Onn A, Sandler A. Angiogenesis and lung cancer: prognostic and therapeutic implications. J Clin Oncol. [Internet]. 2005 [cited 2016 Mar 22];23: 3243-3256 Available from: http://jco.ascopubs.org/content/23/14/3243.abstract

131. Pugh CW, Ratcliffe PJ. Regulation of angiogenesis by hypoxia: role of the HIF system. Nat Med. [Internet]. Nature Publishing Group; 2003 [cited 2016 Jun 14];9: 677-684 Available from: http://www.nature.com/doifinder/10.1038/nm0603-677

132. Carmeliet P. VEGF as a key mediator of angiogenesis in cancer. Oncology [Internet]. Karger Publishers; 2005 [cited 2015 Jul 20];69 Suppl 3:4-10 Available from: http://www.karger.com/Article/FullText/88478

133. Ke H, Masoumi KC, Ahlqvist K, Seckl MJ, Rydell-Törmänen K, Massoumi R. Nemo-like kinase regulates the expression of vascular endothelial growth factor (VEGF) in alveolar epithelial cells. Sci Rep. [Internet]. 2016 [cited 2016 Jun 14];6:23987. Available from: http://www.ncbi.nlm.nih.gov/pubmed/27035511.

134. Rapp J, Kiss E, Meggyes M, Szabo-Meleg E, Feller D, Smuk G, et al. Increased WNT5a in squamous cell lung carcinoma inhibits endothelial cell motility. BMC Cancer [Internet]. 2016 [cited 2016 Dec 15];16:915. Available from: http://www.ncbi.nlm.nih.gov/pubmed/27876017.

135. Nagy JA, Chang S-H, Dvorak AM, Dvorak HF. Why are tumour blood vessels abnormal and why is it important to know? Br J Cancer [Internet]. Cancer Research UK; 2009 [cited 2015 Oct 27];100:865-869 Available from: https://doi.org/10.1038/sj.bjc.6604929
136. Ziyad S, Iruela-Arispe ML. Molecular mechanisms of tumor angiogenesis. Genes Cancer [Internet]. 2011 [cited 2016 Mar 22];2:1085-1096 Available from: http:// www.pubmedcentral.nih.gov/articlerender.fcgi?artid=3411131\&tool= pmcentrez\&rendertype $=$ abstract

137. Yao L, Sun B, Zhao X, Zhao X, Gu Q, Dong X, et al. Overexpression of WNT5a promotes angiogenesis in NSCLC. Biomed Res Int. [Internet]. 2014 [cited 2015 Oct 27];2014:832562 Available from: http://www.pubmedcentral.nih.gov/ articlerender.fcgi? artid=4066942\&tool=pmcentrez\&rendertype=abstract

138. Shukla S, Sinha S, Khan S, Kumar S, Singh K, Mitra K, et al. Cucurbitacin B inhibits the stemness and metastatic abilities of NSCLC via down-regulation of canonical WNT/ß-catenin signaling axis. Sci Rep. [Internet]. 2016 [cited 2016 Mar 22];6:21860 Available from: http://www.pubmedcentral.nih.gov/ articlerender.fcgi?artid $=4764833 \&$ tool=pmcentrez\&rendertype $=$ abstract

139. Yeo E-J, Cassetta L, Qian B-Z, Lewkowich I, Li J, Stefater JA, et al. Myeloid WNT7b mediates the angiogenic switch and metastasis in breast cancer. Cancer Res. [Internet]. 2014 [cited 2016 Feb 29];74:2962-2973 Available from: http://www.pubmedcentral.nih.gov/articlerender.fcgi?artid= 4137408\&tool=pmcentrez\&rendertype=abstract

140. Larue L, Bellacosa A. Epithelial-mesenchymal transition in development and cancer: role of phosphatidylinositol 3' kinase/AKT pathways. Oncogene [Internet]. 2005 [cited 2016 Jan 24];24:7443-7454. Available from: http://www.ncbi.nlm.nih. gov/pubmed/16288291.

141. Ceteci F, Ceteci S, Karreman C, Kramer BW, Asan E, Götz R, et al. Disruption of tumor cell adhesion promotes angiogenic switch and progression to micrometastasis in RAF-driven murine lung cancer. Cancer Cell [Internet]. 2007 [cited 2016 mar 22];12:145-159. Available from: http://www.ncbi.nlm. nih.gov/pubmed/17692806.

142. Zhang X-X, Zhang $L-L$, Yang H-L, Wang X-W. Mechanism of WNT/ $\beta$-catenin signaling pathway in enhanced malignant phenotype of non-small cell lung cancer induced by anti-angiogenesis therapy. Asian Pac J Trop Med. [Internet]. 2016 [cited 2016 mar 22];9:58-62. Available from: http://www. ncbi.nlm.nih.gov/pubmed/26851788.

143. Rao JS, Gondi C, Chetty C, Chittivelu S, Joseph PA, Lakka SS. Inhibition of invasion, angiogenesis, tumor growth, and metastasis by adenovirusmediated transfer of antisense UPAR and MMP-9 in non-small cell lung cancer cells. Mol Cancer Ther. [Internet]. 2005 [cited 2016 Mar 22];4:13991408 Available from: http://www.pubmedcentral.nih.gov/articlerender. fcgi?artid=1343495\&tool=pmcentrez\&rendertype=abstract

144. Wiranowska M. Matrix Metalloproteinases-Modulating the Tumor Microenvironment. J Carcinog Mutagen. [Internet]. OMICS International; 2015 [cited 2016 Mar 22];06 Available from: http://www.omicsonline.org/ carcinogenesis-mutagenesis-abstract.php?abstract_id=51563

145. Lee CY, Shim HS, Lee S, Lee JG, Kim DJ, Chung KY. Prognostic effect of matrix metalloproteinase-9 in patients with resected Non small cell lung cancer. J Cardiothorac Surg. [Internet]. 2015 [cited 2016 Mar 22];10:44 Available from: http://www.pubmedcentral.nih.gov/articlerender.fcgi?artid= 4379698\&tool=pmcentrez\&rendertype=abstract

146. Lee MA, Park J-H, Rhyu SY, Oh S-T, Kang W-K, Kim H-N. WNT3a expression is associated with MMP-9 expression in primary tumor and metastatic site in recurrent or stage IV colorectal cancer. BMC Cancer [Internet]. BioMed Central; 2014 [cited 2016 Mar 20];14:125 Available from: http://bmccancer. biomedcentral.com/articles/10.1186/1471-2407-14-125

147. Chen X, Meng J, Yue W, Yu J, Yang J, Yao Z, et al. Fibulin-3 suppresses WNT/Bcatenin signaling and lung cancer invasion. Carcinogenesis [Internet]. 2014 [cited 2016 Mar 22];35:1707-1716 Available from: http//www.pubmedcentral.nih.gov/ articlerender.fcgi?artid $=4123641 \&$ tool=pmcentrez\&rendertype=abstract

148. Chen X, Song X, Yue W, Chen D, Yu J, Yao Z, et al. Fibulin-5 inhibits WNT/ $\beta$ catenin signaling in lung cancer. Oncotarget [Internet]. 2015 [cited 2016 Mar 22];6:15022-15034 Available from: http://www.pubmedcentral.nih.gov/ articlerender.fcgi?artid $=4558133 \&$ tool=pmcentrez\&rendertype $=$ abstract

149. Gao Y, Song C, Hui L, Li C, Wang J, Tian Y, et al. Overexpression of RNF146 in non-small cell lung cancer enhances proliferation and invasion of tumors through the WNT/ $\beta$-catenin signaling pathway. PLoS One [Internet]. 2014 [cited 2016 Mar 22];9:e85377 Available from: http://www.pubmedcentral.nih. gov/articlerender.fcgi?artid=3891871\&tool=pmcentrez\&rendertype=abstract

150. Fanjul-Fernandez M, Folgueras AR, Fueyo A, Balbin M, Suarez MF, Fernandez-Garcia MS, et al. Matrix Metalloproteinase Mmp-1a Is Dispensable for Normal Growth and Fertility in Mice and Promotes Lung Cancer Progression by Modulating Inflammatory Responses. J Biol Chem. [Internet]. 2013 [cited 2016 Jun 14];288:14647-14656 Available from: http://www.jbc. org/cgi/doi/10.1074/jbc.M112.439893 
151. Reynolds PR, Kasteler SD, Cosio MG, Sturrock A, Huecksteadt T, Hoidal JR RAGE: developmental expression and positive feedback regulation by Egr-1 during cigarette smoke exposure in pulmonary epithelial cells. Am J Physiol Lung Cell Mol Physiol. [Internet]. 2008 [cited 2016 Jun 14];294:L1094-L1101. Available from: http://www.ncbi.nlm.nih.gov/pubmed/18390831.

152. Bartling B, Fuchs C, Somoza V, Niemann B, Silber R-E, Simm A. Lung level of HMBG1 is elevated in response to advanced glycation end product-enriched food in vivo. Mol Nutr Food Res. [Internet]. 2007 [cited 2016 Jun 14];51:479-487. Available from: http://www.ncbi.nlm.nih.gov/pubmed/17357979.

153. Bartling B, Hofmann H-S, Weigle B, Silber R-E, Simm A. Down-regulation of the receptor for advanced glycation end-products (RAGE) supports non-small cell lung carcinoma. Carcinogenesis [Internet]. 2005 [cited 2016 Jun 14];26:293-301. Available from: http://www.ncbi.nlm.nih.gov/pubmed/15539404.

154. Sparvero $\sqcup$, Asafu-Adjei D, Kang R, Tang D, Amin N, Im J, et al. RAGE (Receptor for Advanced Glycation Endproducts), RAGE ligands, and their role in cancer and inflammation. J Transl Med [Internet]. 2009 [cited 2016 Jun 14];7:17. Available from: http://www.ncbi.n/m.nih.gov/pubmed/19292913.

155. Gridelli C, Maione P, Rossi A, De Marinis F. The role of bevacizumab in the treatment of non-small cell lung cancer: current indications and future developments. Oncologist [Internet]. 2007 [cited 2015 Oct 27];12:1183-1193. Available from: http://www.ncbi.nlm.nih.gov/pubmed/17962612

156. Johnson DH, Fehrenbacher L, Novotny WF, Herbst RS, Nemunaitis JJ, Jablons DM, et al. Randomized phase II trial comparing bevacizumab plus carboplatin and paclitaxel with carboplatin and paclitaxel alone in previously untreated locally advanced or metastatic non-small-cell lung cancer. J Clin Oncol [Internet]. 2004 [cited 2015 Aug 14];22:2184-2191. Available from: http://www.ncbi.nlm.nih.gov/pubmed/15169807.

157. Van der Veldt AAM, Lubberink M, Bahce I, Walraven M, de Boer MP, Greuter HNJM, et al. Rapid decrease in delivery of chemotherapy to tumors after anti-VEGF therapy: implications for scheduling of anti-angiogenic drugs. Cancer Cell [Internet]. Elsevier; 2012 [cited 2016 Mar 7];21:82-91 Available from: http://www.cell.com/article/S1535610811004466/fulltext

158. Kumar S, Arbab AS. Neovascularization in Glioblastoma: Current Pitfall in Anti-angiogenic therapy. Zhong liu za zhi [Internet]. 2013 [cited 2016 Mar 22];1:16-19 Available from: http://www.pubmedcentral.nih.gov/articlerender. fcgi?artid=4073792\&tool=pmcentrez\&rendertype=abstract

159. Pàez-Ribes M, Allen E, Hudock J, Takeda T, Okuyama H, Viñals F, et al. Antiangiogenic therapy elicits malignant progression of tumors to increased local invasion and distant metastasis. Cancer Cell [Internet]. 2009 [cited 2015 Dec 21];15:220-231 Available from: http://www.pubmedcentral.nih.gov/ articlerender.fcgi?artid=2874829\&tool=pmcentrez\&rendertype=abstract

160. Keunen O, Johansson M, Oudin A, Sanzey M, Rahim SAA, Fack F, et al. AntiVEGF treatment reduces blood supply and increases tumor cell invasion in glioblastoma. Proc Natl Acad Sci U S A. [Internet]. 2011 [cited 2016 Mar 22]; 108:3749-3754 Available from: http://www.pubmedcentral.nih.gov/ articlerender.fcgi?artid=3048093\&tool=pmcentrez\&rendertype=abstract

161. Stewart DJ. Tumor and host factors that may limit efficacy of chemotherapy in non-small cell and small cell lung cancer. Crit Rev Oncol Hematol. [Internet]. 2010 [cited 2016 Jun 14];75:173-234. Available from: http://www. ncbi.nlm.nih.gov/pubmed/20047843.

162. Teng $Y$, Wang $X$, Wang $Y$, Ma D. WNT/beta-catenin signaling regulates cancer stem cells in lung cancer A549 cells. Biochem Biophys Res Commun. [Internet]. 2010 [cited 2016 Jun 14];392:373-379. Available from: http://www. ncbi.nlm.nih.gov/pubmed/20074550.

163. Takahashi-Yanaga F, Kahn M. Targeting WNT signaling: can we safely eradicate cancer stem cells? Clin Cancer Res. [Internet]. 2010 [cited 2016 Jun 14];16:31533162. Available from: http://www.ncbi.nlm.nih.gov/pubmed/20530697.

164. Jiang $H-L$, Jiang $L-M$, Han W-D. WNT/B-catenin signaling pathway in lung cancer stem cells is a potential target for the development of novel anticancer drugs. J BUON. [Internet]. [cited 2016 Jun 14];20:1094-1100. Available from: http://www.ncbi.nlm.nih.gov/pubmed/26416062.

165. Abdullah LN, Chow EK-H. Mechanisms of chemoresistance in cancer stem cells. Clin Transl Med. [Internet]. 2013 [cited 2016 Jun 14];2:3. Available from: http://www.ncbi.nlm.nih.gov/pubmed/23369605.

166. Stacy AE, Jansson PJ, Richardson DR. Molecular pharmacology of ABCG2 and its role in chemoresistance. Mol Pharmacol [Internet]. 2013 [cited 2016 Jun 14];84:655-669. Available from: http://www.ncbi.nlm.nih.gov/pubmed/ 24021215.

167. Zhou S, Schuetz JD, Bunting KD, Colapietro AM, Sampath J, Morris JJ, et al. The $A B C$ transporter Bcrp1/ABCG2 is expressed in a wide variety of stem cells and is a molecular determinant of the side-population phenotype. Nat
Med. [Internet]. 2001 [cited 2016 Jun 14];7:1028-1034. Available from: http://www.ncbi.nlm.nih.gov/pubmed/11533706.

168. Corrêa S, Binato R, Du Rocher B, Castelo-Branco MT, Pizzatti L, Abdelhay E, et al. WNT/B-catenin pathway regulates $A B C B 1$ transcription in chronic myeloid leukemia. BMC Cancer [Internet]. BioMed Central; 2012 [cited 2016 Jun 14];12: 303 Available from: http://bmccancer.biomedcentral.com/articles/10.1186/ 1471-2407-12-303

169. Jang SH, Wientjes MG, Au JL. Kinetics of P-glycoprotein-mediated efflux of paclitaxel. J Pharmacol Exp Ther. [Internet]. 2001 [cited 2016 Jun 14];298: 1236-1242. Available from: http://www.ncbi.nlm.nih.gov/pubmed/11504826.

170. Glimelius B, Garmo H, Berglund A, Fredriksson LA, Berglund M, Kohnke H, et al. Prediction of irinotecan and 5 -fluorouracil toxicity and response in patients with advanced colorectal cancer. Pharmacogenomics J. [Internet]. 2011 [cited 2016 Jun 14];11:61-71. Available from: http://www.ncbi.nlm.nih. gov/pubmed/20177420.

171. Ota S, Ishii G, Goto K, Kubota K, Kim YH, Kojika M, et al. Immunohistochemical expression of BCRP and ERCC1 in biopsy specimen predicts survival in advanced non-small-cell lung cancer treated with cisplatin-based chemotherapy. Lung Cancer [Internet]. 2009 [cited 2016 Jun 14];64:98-104. Available from: http://www.ncbi.nlm.nih.gov/pubmed/18823676.

172. Kim YH, Ishii G, Goto K, Ota S, Kubota K, Murata Y, et al. Expression of breast cancer resistance protein is associated with a poor clinical outcome in patients with small-cell lung cancer. Lung Cancer [Internet]. 2009 [cited 2016 Jun 14];65:105-111. Available from: http://www.ncbi.nlm.nih.gov/ pubmed/19036469.

173. Niida A, Hiroko T, Kasai M, Furukawa Y, Nakamura Y, Suzuki Y, et al. DKK1, a negative regulator of WNT signaling, is a target of the beta-catenin/TCF pathway. Oncogene [Internet]. 2004 [cited 2016 Jun 14];23:8520-8526. Available from: http://www.ncbi.nlm.nih.gov/pubmed/15378020.

174. Salim H, Zong D, Hååg P, Novak M, Mörk B, Lewensohn R, et al. DKK1 is a potential novel mediator of cisplatin-refractoriness in non-small cell lung cancer cell lines. BMC Cancer [Internet]. BioMed Central; 2015 [cited 2016 Oct 21];15:628 Available from: http://bmccancer.biomedcentral.com/articles/ 10.1186/s12885-015-1635-9

175. Agrawal M, Abraham J, Balis FM, Edgerly M, Stein WD, Bates S, et al. Increased 99mTc-sestamibi accumulation in normal liver and drug-resistant tumors after the administration of the glycoprotein inhibitor, XR9576. Clin Cancer Res. [Internet]. 2003 [cited 2016 Jun 14];9:650-656. Available from: http://www.ncbi.nlm.nih.gov/pubmed/12576431.

176. Kelly RJ, Draper D, Chen CC, Robey RW, Figg WD, Piekarz RL, et al. A pharmacodynamic study of docetaxel in combination with the Pglycoprotein antagonist tariquidar (XR9576) in patients with lung, ovarian, and cervical cancer. Clin Cancer Res. [Internet]. 2011 [cited 2016 Jun 14];17: 569-580. Available from: http://www.ncbi.nlm.nih.gov/pubmed/21081657.

177. Kelly RJ, Robey RW, Chen CC, Draper D, Luchenko V, Barnett D, et al. A pharmacodynamic study of the P-glycoprotein antagonist CBT- $1^{\oplus}$ in combination with paclitaxel in solid tumors. Oncologist [Internet]. 2012 [cited 2016 Jun 14];17:512. Available from: http://www.ncbi.nlm.nih.gov/ pubmed/22416063.

178. ClinicalTrials.gov [Internet]. Available from: https://clinicaltrials.gov/.

179. Raaijmakers MHGP. ATP-binding-cassette transporters in hematopoietic stem cells and their utility as therapeutical targets in acute and chronic myeloid leukemia. Leukemia [Internet]. Nature Publishing Group; 2007 [cited 2016 Jun 14];21:20942102 Available from: http://www.nature.com/doifinder/10.1038/sj.leu.2404859

180. Tsimberidou A-M. Targeted therapy in cancer. Cancer Chemother. Pharmacol. [Internet]. Springer Berlin Heidelberg; 2015 [cited 2016 Oct 21];76:1113-1132 Available from: http://link.springer.com/10.1007/s00280-015-2861-1

181. Tai D, Wells K, Arcaroli J, Vanderbilt C, Aisner DL, Messersmith WA, Lieu CH. Targeting the WNT Signaling Pathway in Cancer Therapeutics. Oncologist. [Internet]. 2015 [Cited 2016 Dec 02]; 20(10):1189-1198. Available from: https://www.ncbi.nlm.nih.gov/pmc/articles/PMC4591954/

182. Gross JC, Boutros M. Secretion and extracellular space travel of WNT proteins. Curr Opin Genet Dev. [Internet]. 2013 [cited 2016 Oct 20];23:385-390. Available from: http://www.ncbi.nlm.nih.gov/pubmed/23540564.

183. Breslin S, O'Driscoll L. Three-dimensional cell culture: the missing link in drug discovery. Drug Discovery Today. [Internet]. 2013 [cited 2017 march 02]; 18: 240-249. Available from: http://www.ncbi.nlm.nih.gov/pubmed/23540564.

184. Guo S, Tan L, Pu W, Wu J, Xu K, Wu J, et al. Quantitative assessment of the diagnostic role of APC promoter methylation in non-small cell lung cancer. Clin Epigenetics [Internet]. 2014 [cited 2017 may 12];6:5. Available from: http://www.ncbi.nlm.nih.gov/pubmed/24661338. 
185. Xu H-T, Wang L, Lin D, Liu Y, Liu N, Yuan X-M, et al. Abnormal $\beta$-Catenin and Reduced Axin Expression Are Associated With Poor Differentiation and Progression in Non-Small Cell Lung Cancer. Am J Clin Pathol [Internet]. Oxford University Press; 2006 [cited 2017 May 12];125:534-541 Available from: https:/academic.oup.com/ ajcp/article-lookup/doi/10.1309/0MDY02KHEW1F6RT6

186. Li X-Q, Yang X-L, Zhang G, Wu S-P, Deng X-B, Xiao S-J, et al. Nuclear $\beta$ catenin accumulation is associated with increased expression of Nanog protein and predicts poor prognosis of non-small cell lung cancer. J Transl Med [Internet]. 2013 [cited 2017 may 12];11:114. Available from: http://www. ncbi.nlm.nih.gov/pubmed/23648139.

187. Dong L, Qu L, Chu L, Zhang X, Liu Y. Serum level of DKK-1 and its prognostic potential in non-small cell lung cancer. Diagn Pathol [lnternet]. 2014 [cited 2017 may 12];9:52. Available from: http://www.ncbi.nlm.nih.gov/pubmed/24612589.

188. Yue W, Sun Q, Dacic S, Landreneau RJ, Siegfried JM, Yu J, et al. Downregulation of Dkk3 activates -catenin/TCF-4 signaling in lung cancer Carcinogenesis [Internet]. 2007 [cited 2017 may 12];29:84-92. Available from: http://www.ncbi.nlm.nih.gov/pubmed/18048388.

189. Wei Q, Zhao Y, Yang Z-Q, Dong Q-Z, Dong X-J, Han Y, et al. Dishevelled family proteins are expressed in non-small cell lung cancer and function differentially on tumor progression. Lung Cancer [Internet]. 2008 [cited 2017 may 12];62: 181-192. Available from: http://www.ncbi.nlm.nih.gov/pubmed/18692936.

190. Uematsu K, He B, You L, Xu Z, McCormick F, Jablons DM. Activation of the WNT pathway in non small cell lung cancer: evidence of dishevelled overexpression. Oncogene [Internet]. 2003 [cited 2017 may 15];22:72187221. Available from: http://www.ncbi.nlm.nih.gov/pubmed/14562050

191. Wang H, Xu M, Ma J, Zhang Y, Xie C. Frizzled-8 as a putative therapeutic target in human lung cancer. Biochem Biophys Res Commun. [Internet]. 2012 [cited 2017 may 12];417:62-66. Available from: http://www.ncbi.nlm. nih.gov/pubmed/22138402.

192. Zheng H, Saito H, Masuda S, Yang X, Takano Y. Phosphorylated GSK3betaser9 and EGFR are good prognostic factors for lung carcinomas. Anticancer Res. [Internet]. [cited 2017 May 12];27:3561-3569. Available from: http:// www.ncbi.nlm.nih.gov/pubmed/17972518.

193. Fukui T, Kondo M, Ito G, Maeda O, Sato N, Yoshioka H, et al. Transcriptiona silencing of secreted frizzled related protein 1 (SFRP1) by promoter hypermethylation in non-small-cell lung cancer. Oncogene [Internet]. 2005 [cited 2017 may 12];24:6323-6327. Available from: http://www.ncbi.nlm.nih gov/pubmed/16007200.

194. Li C, Wang Y, Cui Z, Wang E. Expression of T cell factor-4 in non-small-cell lung cancer. Chin Med J (Engl). [Internet]. 2005 [cited 2017 may 12]:118: 136-140. Available from: http://www.ncbi.nlm.nih.gov/pubmed/15667799.

195. Mazieres J, He B, You L, Xu Z, Lee AY, Mikami I, et al. WNT Inhibitory Factor1 Is Silenced by Promoter Hypermethylation in Human Lung Cancer. Cancer Res. [Internet]. 2004 [cited 2017 may 15];64:4717-20. Available from: http://www.ncbi.nlm.nih.gov/pubmed/15256437.

196. He B, You L, Uematsu K, Xu Z, Lee AY, Matsangou M, et al. A monoclonal antibody against WNT-1 induces apoptosis in human cancer cells. Neoplasia [Internet]. [cited 2017 May 15];6:7-14. Available from: http://www.ncbi.nlm. nih.gov/pubmed/15068666.

197. Huang C, Ma R, Xu Y, Li N, Li Z, Yue J, et al. WNT2 promotes non-small cell lung cancer progression by activating WNT/ß-catenin pathway. Am J Cancer Res. [Internet]. 2015 [cited 2017 may 15];5:1032-1046. Available from: http://www.ncbi.nlm.nih.gov/pubmed/26045984.

198. Tennis MA, VanScoyk M, Freeman S, Winn RA. Promoter Hypermethylation Leads to Loss of WNT7a in Non-Small Cell Lung Cancer. Proc Am Thorac Soc [Internet]. American Thoracic Society; 2012 [cited 2017 May 15];9:83-84 Available from: http://www.atsjournals.org/doi/abs/10.1513/pats.9.2.83a

199. Vesel M, Rapp J, Feller D, Kiss E, Jaromi L, Meggyes M, et al. ABCB1 and $A B C G 2$ drug transporters are differentially expressed in non-small cell lung cancers (NSCLC) and expression is modified by cisplatin treatment via altered WNT signaling. Respir Res. [Internet]. BioMed Central; 2017 [cited 2017 May 15];18:52 Available from: http://respiratory-research.biomedcentral. com/articles/10.1186/s12931-017-0537-6

200. Kim NH, Kim HS, Kim N-G, Lee I, Choi H-S, Li X-Y, et al. p53 and microRNA-34 are suppressors of canonical WNT signaling. Sci Signal. [Internet]. NIH Public Access; 2011 [cited 2016 Nov 22];4:ra71. Available from: http://www.ncbi.nlm.nih.gov/pubmed/22045851.

201. Guinot A, Oeztuerk-Winder F, Ventura J-J. miR-17-92/p38 Dysregulation Enhances WNT Signaling and Selects Lgr6+ Cancer Stem-like Cells during Lung Adenocarcinoma Progression. Cancer Res. [Internet]. 2016 [cited 2016
Nov 22];76:4012-4022 Available from: http://cancerres.aacrjournals.org/cgi/ doi/10.1158/0008-5472.CAN-15-3302

202. Wu D, Shi M, Fan X-D. Mechanism of miR-21 via WNT/ß-catenin signaling pathway in human A549 lung cancer cells and Lewis lung carcinoma in mice. Asian Pac J Trop Med. [Internet]. 2015 [cited 2016 Nov 22];8:479-484 Available from: http://linkinghub.elsevier.com/retrieve/pii/S1995764515000437

203. Tan M, Wu J, Cai Y. Suppression of WNT signaling by the miR-29 family is mediated by demethylation of WIF-1 in non-small-cell lung cancer. Commun: Biochem. Biophys. Res; 2013.

204. Xu W, Ji J, Xu Y, Liu Y, Shi L, Liu Y, et al. MicroRNA-191, by promoting the EMT and increasing CSC-like properties, is involved in neoplastic and metastatic properties of transformed human bronchial epithelial cells. Mol Carcinog. [Internet]. 2015 [cited 2016 Nov 22];54:E148-E161 Available from: http://doi.wiley.com/10.1002/mc.22221

205. Wang Y, Xia H, Zhuang Z, Miao L, Chen X, Cai H. Axl-altered microRNAs regulate tumorigenicity and gefitinib resistance in lung cancer. Cell Death Dis. [Internet]. Nature Publishing Group; 2014 [cited 2016 Nov 22];5:e1227. Available from: http://www.ncbi.nlm.nih.gov/pubmed/24832599.

206. Mo X-M, Li H-H, Liu M, Li Y-T. Down-regulation of GSK3 3 by miR-544a to maintain self-renewal ability of lung caner stem cells. Oncol Lett. [Internet]. Spandidos Publications; 2014 [cited 2016 Nov 22];8:1731-1734. Available from: http://www.ncbi.n/m.nih.gov/pubmed/25202400.

207. Zhou R, Zhou X, Yin Z, Guo J, Hu T, Jiang S, et al. MicroRNA-574-5p promotes metastasis of non-small cell lung cancer by targeting PTPRU. Sci Rep. [Internet]. Nature Publishing Group; 2016 [cited 2016 Nov 22];6:35714 Available from: http://www.nature.com/articles/srep35714

208. Jang JS, Jeon H-S, Sun Z, Aubry MC, Tang H, Park C-H, et al. Increased miR708 expression in NSCLC and its association with poor survival in lung adenocarcinoma from never smokers. Clin Cancer Res. [Internet]. NIH Public Access; 2012 [cited 2016 Nov 22];18:3658-3667. Available from: http://www. ncbi.nlm.nih.gov/pubmed/22573352.

\section{Submit your next manuscript to BioMed Central and we will help you at every step:}

- We accept pre-submission inquiries

- Our selector tool helps you to find the most relevant journal

- We provide round the clock customer support

- Convenient online submission

- Thorough peer review

- Inclusion in PubMed and all major indexing services

- Maximum visibility for your research

Submit your manuscript at www.biomedcentral.com/submit
Ciomed Central 